\title{
The Moosehorn Plutonic Suite, southeastern Maine and southwestern New Brunswick: age, petrochemistry, and tectonic setting
}

\author{
K. J. Mclaughlin ${ }^{1}$, S.M. Barr ${ }^{1 *}$, M.D. Hill ${ }^{2}$, M.D. Thompson ${ }^{3}$, J. Ramezani ${ }^{4}$, and P.H. Reynolds 5 \\ 1. Department of Geology, Acadia University, Wolfville, Nova Scotia, Canada B4P 2R6 \\ 2. Northeastern University, Boston, Massachusetts 02115 USA \\ 3. Geology Department, Wellesley College, Wellesley, Massachusetts 02481 USA \\ 4. Department of Earth, Atmospheric, and Planetary Sciences, Massachusetts Institute of Technology, \\ Cambridge, Massachusetts 02139 USA \\ 5. Department of Earth Sciences, Dalhousie University, Halifax, Nova Scotia, Canada B3H 3J5 \\ *Corresponding author: <sandra.barr@acadiau.ca>
}

Date received:September 12, 2003 I Date accepted: March 3, 2004

\begin{abstract}
The Moosehorn Plutonic Suite in the coastal Maine magmatic province covers an area of approximately $250 \mathrm{~km}^{2}$ in the area of Calais, Maine, and St. Stephen, New Brunswick. Based on a compilation of previous work combined with new field mapping, geochronology, and petrochemical data, the Moosehorn Plutonic Suite (MPS) is interpreted to consist mainly of five approximately contemporaneous plutons: Staples Mountain Gabbro, St. Stephen Gabbro, Calais Quartz Diorite, Baring Granite, and Elliott Mountain Diorite. The layered, sill-like Staples Mountain Gabbro is mainly mafic, whereas the larger St. Stephen Gabbro consists of a core of dunite and troctolite, surrounded by olivine gabbro and gabbro layers. The latter unit grades to quartz diorite of the Calais Quartz Diorite, the most extensive component of the MPS. The Baring Granite consists of medium-grained biotite monzogranite, which is widely mingled with quartz diorite and diorite of the Calais Quartz Diorite. The latest pluton of the MPS appears to be the Elliott Mountain Diorite, which consists mainly of texturally varied dioritic rocks. Each pluton of the MPS is interpreted to have formed by magma differentiation to produce a range of derived compositions. Evidence for mingling and mixing between magmas is also widespread in the MPS, but was not investigated during this study.

A sample from the Baring Granite yielded a U-Pb (zircon) crystallization age of $421.1 \pm 0.8 \mathrm{Ma}$ ) and phlogopite from the olivine gabbro unit of the St. Stephen Gabbro yielded a ${ }^{40} \mathrm{Ar} /{ }^{39} \mathrm{Ar}$ cooling age of $421 \pm 4 \mathrm{Ma}$. The gabbroic parts of the St. Stephen Pluton and the Calais Quartz Diorite are similar in petrochemistry to mafic and intermediate parts of the Bocabec Pluton of the Saint George Batholith whereas the Baring Granite is similar to the granitic parts of the Bocabec Pluton. Plutons of the MPS generally have calc-alkalic to within-plate chemical characteristics, and their slightly negative $(-0.4)$ to moderately positive $(+3.4) \varepsilon_{\mathrm{Nd}}$ values are consistent with formation by melting of primitive lower crust, such as may have been present below the Mascarene and Ellsworth terranes. Melting likely occurred in a back-arc setting related to juxtaposition in the late Silurian between these terranes and more outboard terranes of the northern Appalachian orogen.
\end{abstract}

\section{RÉSUMÉ}

Le cortège plutonique de Moosehorn dans la province magmatique et côtière du Maine couvre une superficie d'environ 250 kilomètres carrés dans la région de Calais, au Maine, et de St. Stephen, au Nouveau-Brunswick. Selon une compilation de travaux antérieurs combinés à de nouvelles données pétrochimiques, géochronologiques et cartographiques obtenues sur le terrain, le cortège plutonique de Moosehorn (CPM) est interprété comme un ensemble principalement composé de cinq plutons plus ou moins cinq syngénétiques : le gabbro du mont Staples, le gabbro de St. Stephen, la diorite quartzite de Calais, le granite de Baring et la diorite du mont Elliott. Le gabbro stratifié en filons-couches du mont Staples est principalement mafique, tandis que le gabbro plus vaste de St. Stephen est constitué d'un noyau de dunite et de troctolite, entouré de strates de gabbro et de gabbro à olivine. Cette dernière unité se classe parmi la diorite quartzite du pluton de diorite quartzite de Calais, l'élément le plus étendu du CPM. Le granite de Baring est constitué de monzogranite à biotite à grain moyen, abondamment mêlé à de la diorite quartzite et à de la diorite du pluton de diorite quartzite de Calais. Le pluton le plus récent du CPM semble être la diorite du mont Elliott, principalement constituée de roches dioritiques de textures diverses. Chaque pluton du CPM se serait, selon les interprétations, formé par différenciation magmatique ayant produit un éventail de compositions dérivées. Les indices témoignant d'un mélange et d'un mixage entre les magmas sont également répandus dans le CPM, mais ils n’ont pas été analysés dans le cadre de la présente étude. 
Un échantillon du granite de Baring a été situé à 421,1 $\pm 0,8$ Ma par cristallisation au U-Pb (à partir du zircon) et une datation de la phlogopite de l'unité de gabbro à olivine du gabbro de St. Stephen a situé son âge de refroidissement ${ }^{40} \mathrm{Ar} /{ }^{39} \mathrm{Ar}$ à $421 \pm 4 \mathrm{Ma}$. Les parties gabbrö̈ques du pluton de St. Stephen et de la diorite quartzite de Calais présentent une pétrochimie semblable aux parties mafiques et intermédiaires du pluton de Bocabec du batholite de Saint George, tandis que le granite de Baring ressemble aux parties granitiques du pluton de Bocabec. Les plutons du CPM possèdent généralement des caractéristiques chimiques calco-alcalines à intra-plaque, et leurs valeurs $\varepsilon_{\mathrm{Nd}}$ légèrement négatives $(-0,4)$ à moyennement positives $(+3,4)$ correspondent à une formation par fusion de la croûte inférieure primitive, comme celle pouvant être survenue au-dessous des terranes de Mascarene et d'Ellsworth. La fusion est probablement survenue dans un cadre arrière-arc apparenté à une juxtaposition de ces terranes et des terranes plus limitrophes de l'orogène du nord des Appalaches au cours du Silurien tardif.

[Traduit par la rédaction]

\section{INTRODUCTION}

The coastal Maine magmatic province (Fig. 1) contains voluminous plutonic and volcanic rocks of Silurian and Devonian age and dominantly mafic and felsic compositions (e.g., Hogan and Sinha 1989; Seaman et al. 1999). The focus of this study, the Moosehorn Plutonic Suite (MPS), is part of the coastal Maine magmatic province, exposed over an area of about $250 \mathrm{~km}^{2}$ in the vicinity of Calais, Maine, and St. Stephen, New Brunswick (Fig. 1). The MPS was previously termed the Moosehorn Igneous (or Intrusive) Complex (e.g., Ludman and Hill 1986; Hogan and Sinha 1989; Jurinski 1990; Hill 1991), and includes gabbroic, dioritic, and granitic plutons in the vicinity of the Moosehorn Wilderness Preserve south of Calais, Maine. Complex intrusive relationships between the mafic and felsic components of these units were documented by the above authors and also by others such as Abbott (1986) and Hill and Abbott (1989). They described evidence of magma mingling, and concluded that the gabbroic, dioritic, and granitic magmas that formed these plutons were coeval. Abbott $(1977,1986)$ demonstrated that the plutonic rocks assigned here to the MPS are older than the Devonian Red Beach Granite and hence suggested a Silurian-Devonian age. A Devonian age was suggested by Ludman and Hill(1990), but Jurinski(1990) suggested that a Silurian age is more likely, based on his U-Pb (zircon) age of $434 \pm 9 \mathrm{Ma}$.

The purpose of this paper is to describe the distribution and petrology of plutons that make up the Moosehorn Plutonic Suite, to present new U-Pb (zircon) and ${ }^{40} \mathrm{Ar} /{ }^{39} \mathrm{Ar}$ data that closely constrain the age of the MPS, and to interpret its petrogenesis and tectonic setting at the time of emplacement. Based on petrological and age similarities, we further suggest that the Bocabec Pluton and Utopia Granite of the Saint George Batholith in southwestern New Brunswick are equivalent to parts of the MPS, and hence that the coastal Maine magmatic province should be extended into southwestern New Brunswick.

\section{GEOLOGICAL SETTING}

Several fault-bounded geological terranes have been recognized in southern Maine and southwestern New Brunswick
(Fig. 1). The MPS stitches the boundary between the St. Croix on the northwest and Mascarene (on the southeast) terranes of Fyffe and Fricker (1987) or St. Croix and Ellsworth terranes of Robinson et al. (1998). Rocks of the St. Croix terrane intruded by the MPS are mainly shale and quartz-rich sandstone of the Cambrian-Ordovician Cookson Group. The Mascarene terrane in the study area is represented by Silurian rocks of the Mascarene Group, including conglomerate, volcanic and volcaniclastic rocks, sandstone, and shale (Fyffe et al. 1999). These Cambrian-Ordovician and Silurian rocks are contact metamorphosed and locally migmatized (Hussey et al. 1967; Ludman and Hill 1990) by the MPS, and also occur as xenoliths and roof pendants in the MPS.

Other plutonic rocks occur around the MPS, including the Pocomoonshine Gabbro-Diorite (Westerman 1972) to the west, the Meddybemps and Charlotte granites to the south and southeast, and the Red Beach Granite to the east (Figs. 1, 2). Small bodies of granite intruded into the Elliott Mountain Diorite may be related to the Red Beach or Charlotte granites (Abbott 1986). All of these granitic bodies intruded plutons of the MPS, although the age difference is not well constrained by existing geochronology (e.g., Hill and Abbott 1989). The Pocomoonshine Gabbro-Diorite, for which a ${ }^{40} \mathrm{Ar} /{ }^{39} \mathrm{Ar}$ (hornblende) age of $422.7 \pm 3 \mathrm{Ma}$ has been reported (West et al. 1992), is not in contact with units of the MPS but may be of similar age. The other granitic units are assumed to be significantly younger (Devonian) and not included in the MPS (e.g. Amos 1963; Abbott 1986; Ludman and Hill 1990).

Although Hogan and Sinha (1989) stopped their map of the coastal Maine magmatic province at the Canadian border, the presence of Silurian-Devonian gabbroic to granitic plutons of the Saint George Batholith (e.g., McLeod 1990; McLeod et al.1994) suggests that it extends across the international border into southwestern New Brunswick (Fig. 1, 2). The few maps that show details of plutonic units on both sides of the border (e.g., Ruitenberg and McCutcheon 1978) suggest continuity between the Bocabec Pluton of the Saint George Batholith and the unit of the MPS here termed the Elliott Mountain Diorite. The Bocabec Pluton consists of gabbroic, dioritic, granodioritic, and granitic rocks with complex contact relationships (Fyffe 1971; McLeod et al. 1994) that appear analogous to those among some plutons of the MPS. The Utopia Granite part of 


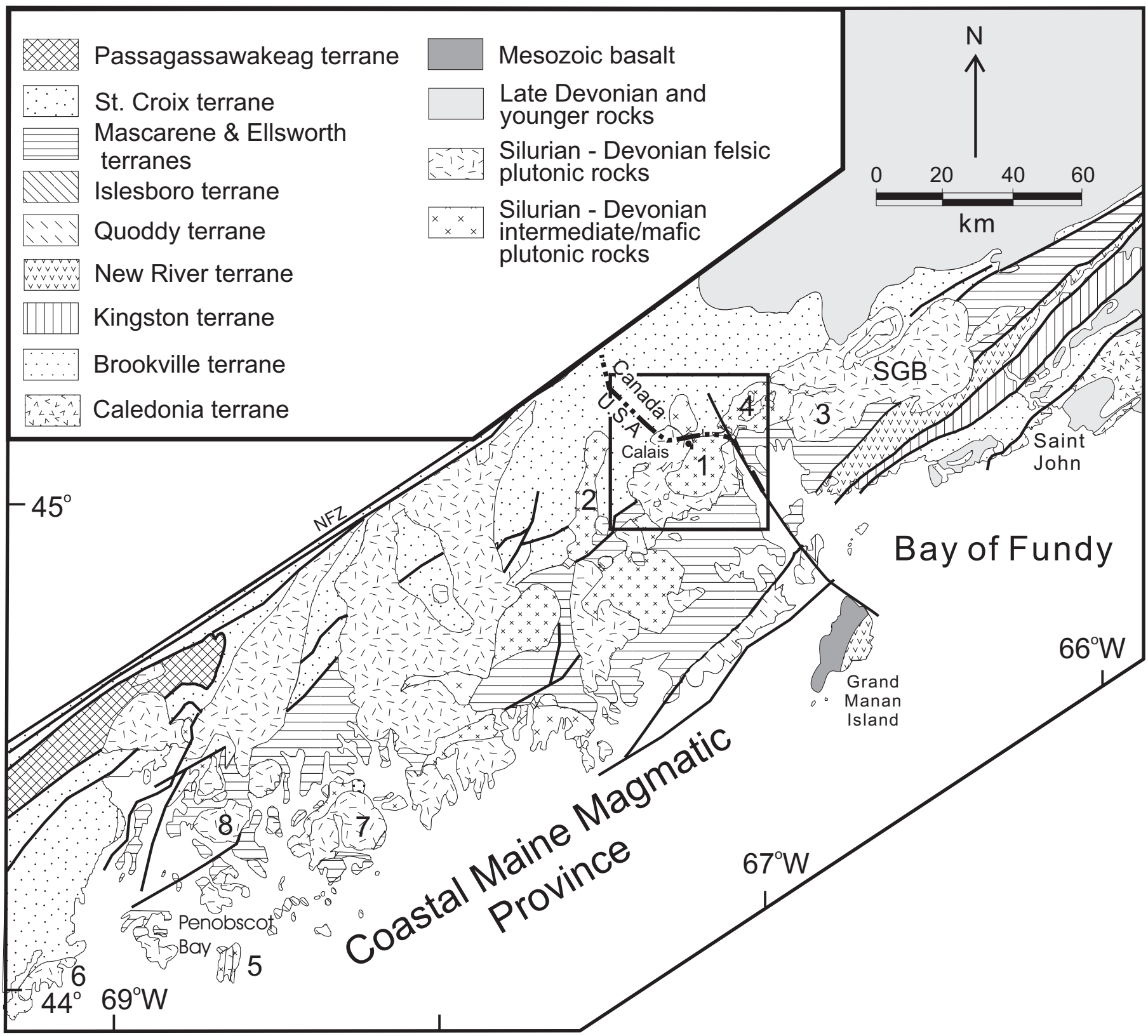

Fig.1 Simplified geological map of southern New Brunswick and southeastern Maine, showing the location of the study area (box) and other features referred to in the text. Units: 1, Moosehorn Plutonic Suite; 2, Pocomoonshine Gabbro-Diorite; 3, Utopia Granite; 4, Bocabec Pluton; 5, South Penobscot Pluton; 6, Spruce Head Pluton; 7, Cadillac Mountain intrusive complex; 8, Sedgewick Pluton. Abbreviations: SGB, Saint George Batholith; NFZ, Norumbega fault zone. Terranes are from Fyffe and Fricker (1987), Robinson et al. (1998), and Barr et al. (2002). Map is modified from Hogan and Sinha (1989).

the Saint George Batholith intruded the Bocabec Pluton, but locally is veined by granodiorite of the Bocabec Pluton; the granodiorite was interpreted by McLeod (1990) and Fyffe (1971) as a zone of commingled rocks between the two plutons, and McLeod (1990) referred to the Bocabec and Utopia plutons collectively as the Digdeguash Lake Intrusive Suite.

\section{PLUTONS OF THE MOOSEHORN PLUTONIC SUITE}

\section{Terminology}

As noted in the Introduction, consistency has yet to be attained in published terminology for plutonic units in the study area. Ludman and Hill (1986) used Moosehorn Intrusive 


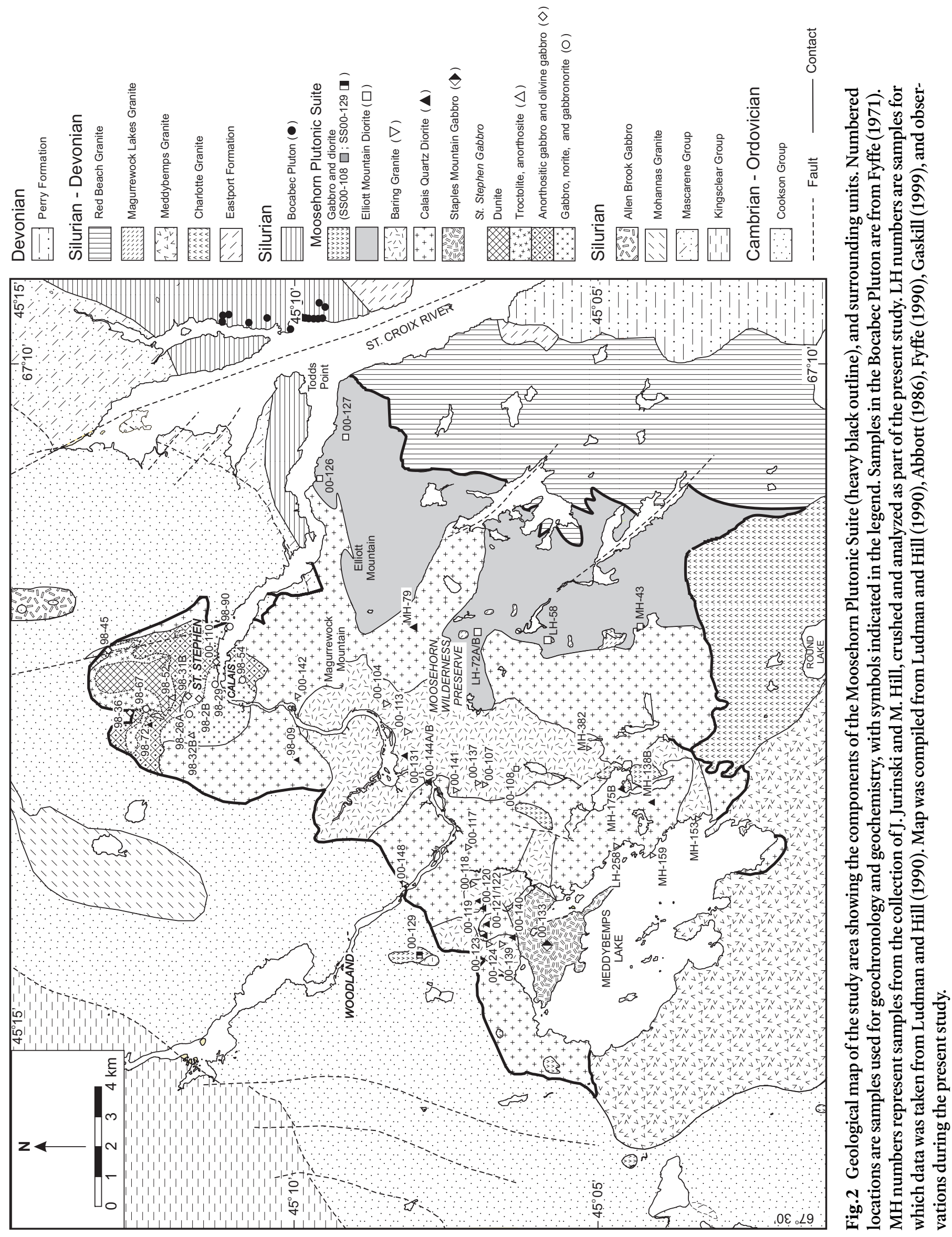


Table 1. Summary of petrographic features of main units* in the MPS.

\begin{tabular}{|c|c|c|c|c|c|}
\hline & Staples Mountain Gabbro & St. Stephen Gabbro & Calais Quartz Diorite & Baring Granite & Elliott Mountain Diorite \\
\hline $\begin{array}{l}\text { Principal } \\
\text { rock types }\end{array}$ & $\begin{array}{l}\text { olivine gabbro, anorthositic } \\
\text { gabbro, norite, anorthosite, } \\
\text { gabbro }\end{array}$ & $\begin{array}{l}\text { dunite, troctolite, olivine } \\
\text { gabbro, anorthositic } \\
\text { gabbro, anorthosite, norite, } \\
\text { gabbro }\end{array}$ & $\begin{array}{l}\text { quartz diorite, diorite, } \\
\text { tonalite, granodiorite, } \\
\text { quartz monzonite }\end{array}$ & $\begin{array}{l}\text { syenogranite, } \\
\text { monzogranite, granodiorite, } \\
\text { tonalite }\end{array}$ & $\begin{array}{l}\text { diorite, quartz diorite, } \\
\text {, tonalite, gabbro }\end{array}$ \\
\hline $\begin{array}{l}\text { Primary } \\
\text { minerals }\end{array}$ & $\begin{array}{l}\text { olivine }\left(\mathrm{Fo}_{53-55}\right), \text { plagioclase } \\
\left(\mathrm{An}_{72-53}\right), \operatorname{cpx}(\text { augite and } \\
\text { pigeonite), hornblende } \\
\text { (ferroan pargasite }), \pm \\
\text { orthopyroxene }\left(\mathrm{En}_{70-62}\right)\end{array}$ & $\begin{array}{l}\text { olivine }\left(\mathrm{Fo}_{80-58}\right) \text {, plagioclase } \\
\left(\mathrm{An}_{95-35}\right), \text { opx }\left(\mathrm{En}_{80-70}\right), \mathrm{cpx} \\
\text { (augite-diopside), } \pm \\
\text { hornblende (pargasite- } \\
\text { pargasitic hornblende), } \\
\text { phlogopite-biotite } \\
(\mathrm{Fe} / \mathrm{Fe}+\mathrm{Mg}=12-40)\end{array}$ & $\begin{array}{l}\text { plagioclase }\left(\mathrm{An}_{80-20}\right) \text {, brown } \\
\text { amphibole (ferropargasitic } \\
\text { hornblende to edenitic } \\
\text { hornblende); green } \\
\text { amphibole } \\
\text { (magnesiohornblende to } \\
\text { actinolite), cpx (augite), opx } \\
(\text { En50), quartz, biotite } \\
(\mathrm{Fe} / \mathrm{Fe}+\mathrm{Mg}=40-60)\end{array}$ & $\begin{array}{l}\text { plagioclase }\left(\mathrm{An}_{29-19}\right), \mathrm{K}- \\
\text { feldspar (microcline), } \\
\text { quartz, biotite } \\
(\mathrm{Fe} / \mathrm{Fe}+\mathrm{Mg}=72-80), \pm \\
\text { hornblende }\end{array}$ & $\begin{array}{l}\text { plagioclase }\left(\mathrm{An}_{60-25}\right), \\
\text { amphibole } \\
\text { (magnesiohornblende- } \\
\text { actinolite), cpx }(\text { augite- } \\
\text { diopside), opx }\left(\mathrm{En}_{50}\right), \\
\text { quartz, } \pm \mathrm{K} \text {-feldspar }\end{array}$ \\
\hline $\begin{array}{l}\text { Accessory } \\
\text { minerals }\end{array}$ & magnetite, ilmenite, apatite & $\begin{array}{l}\text { apatite, titanite, pyrrhotite, } \\
\text { chalcopyrite, pentlandite, }\end{array}$ & $\begin{array}{l}\text { apatite, magnetite, zircon, } \\
\text { titanite }\end{array}$ & apatite, zircon & magnetite, apatite, zircon \\
\hline Textures & layering, cumulate & layering, cumulate, ophitic & $\begin{array}{l}\text { medium-grained (m.g.) } \\
\text { hypidiomorphic } \\
\text { inequigranular, sub-ophitic }\end{array}$ & $\begin{array}{l}\text { m.g. hypidiomorphic } \\
\text { inequigranular/seriate } \\
\text { porphyritic }\end{array}$ & $\begin{array}{l}\text { m.g. hypidiomorphic } \\
\text { inequigranular, sub-ophitic }\end{array}$ \\
\hline
\end{tabular}

*Compiled mainly from McLaughlin (2003), except Staples Mountain Gabbro data from Coughlan (1986).

Complex as a collective term for plutonic units in the Calais area; however, Jurinski (1987) and Hogan and Sinha (1989) used the term Moosehorn Igneous Complex. Ludman and Hill (1986) excluded Staples Mountain Gabbro from their Moosehorn Intrusive Complex, although its close spatial association and petrographic features (Fig. 2, Table 1) appear to justify its inclusion.

Hence, as used here, the MPS consists of five plutons termed the Staples Mountain Gabbro, St. Stephen Gabbro, Calais Quartz Diorite, Baring Granite, and Elliott Mountain Diorite (Fig. 2), each named according to its dominant and most characteristic rock type, although each contains a variety of components (Table 1). Smaller bodies of gabbro, diorite, and granite are present throughout these main plutons. The individual pluton names were used by previous workers, except for Elliott Mountain, a new name introduced by McLaughlin (2003) for part of the Calais gabbro/diorite of Hogan and Sinha (1989). Hogan and Sinha (1989) included all of the mafic-intermediate plutonic rocks between the Baring and Red Beach granite bodies in the Calais gabbro/diorite; however, we use the term Calais Quartz Diorite only for the gabbro-diorite intrusive complex of Ludman and Hill $(1986,1990)$, which also contains a substantial component of granite and metasedimentary xenolithic material. We use the name Elliott Mountain Diorite to refer to the gabbro unit of Ludman and Hill (1986, 1990). That unit extends into the adjacent map area of Abbott (1986), who described it as complex mixture of mainly gabbro, diabase, and granodiorite, intruded by younger granite. We consider the Calais and Elliott Mountain units to be different from one another overall, although both contain a wide variety of rock types and distinction between them at the outcrop scale is ambiguous (see below). Similar and probably co-magmatic mafic rock types also occur throughout the Baring Granite unit, as well as in the Meddybemps Granite to the south. Like previous workers, we exclude clearly younger (Devonian?) granitic plutons in the area, such as Meddybemps, Charlotte, and Red Beach (Fig. 2), from the MPS.

Distinction between gabbro and diorite is problematic in the MPS, especially in outcrop and hand specimen. We use the term gabbro when we consider that the rock is, or was originally before alteration, dominated by pyroxene as the ferromagnesian mineral component, and diorite when amphibole is the dominant ferromagnesian mineral. Hence we term the hornblende gabbro of some earlier workers (e.g., Abbott 1986) as diorite.

\section{Intrusive relationships}

The MPS is characterized by complex zones in which diorite forms enclaves in granite, suggesting that the diorite magma was only partially crystallized at the time of emplacement of the granite magma, and that the two magmas commingled (Hill and Abbott 1989; Jurinski 1990; Ludman and Hill 1990; Hill 1991). These enclaves vary in shape from amoeboid to angular, and in size from $\mathrm{cm}$-scale to $\mathrm{m}$-scale, and were described in detail by previous workers (e.g., Hill and Abbott 1989; Jurinski 1990). The dioritic component dominates in the areas included in this study in the Calais Quartz Diorite and Elliott Mountain Diorite, whereas the granitic component dominates in the area shown as Baring Granite (Fig. 2). A complex relationship also appears to exist between dioritic and gabbroic magmas in the MPS, as locally diorite and quartz diorite appears to cross-cut gabbro, and xenoliths of gabbro are present in diorite and quartz diorite, but overall their petrographic and chemical features are gradational. In this study, the boundary between the St. Stephen Gabbro and Calais Quartz Diorite units is drawn so as to exclude, in so far as possible, gabbroic rocks from the latter pluton. Dykes of granite occur in gabbro in both the Staples Mountain and St. Stephen plutons, indicating that the granite is at least slightly younger than (and not mingled with) the 
gabbro magma. Because they are similar in appearance, these granite dykes are assumed to be co-magmatic with the granite that dominates the Baring Granite unit of the MPS.

The Elliott Mountain Diorite is dominated by dioritic rocks (gabbro of Abbott 1986 and Ludman and Hill 1990), although granodiorite and granite are also present, especially in the eastern part of the unit (Abbott 1986). Where observed, the contact between the Calais Quartz Diorite and the Elliott Mountain Diorite appears to be sharp and marked by a reduction in grain size in the diorite as the contact is approached, suggesting the presence of a chilled margin. Based on the lack of observed mingling relationships during this study, we suggest that the Elliott Mountain Diorite may be at least somewhat younger that the Baring Granite, but more detailed mapping is needed along their contact in order to confirm this suggestion. The Elliott Mountain Diorite is older than the Charlotte, Magurrewock Lakes, and Red Beach granites that intrude it on the south and east, and which are excluded from the MPS.

In addition to units included in the five main plutons, small bodies of dioritic and gabbroic rocks (e.g., Woodland Dump gabbro of Ludman and Hill 1990) also are present in the MPS and adjacent units. A few samples were collected from these units for comparison with the main dioritic and gabbroic units of the MPS.

\section{Petrography}

Petrographic features of the main units of the MPS are summarized in Table 1, and commented on briefly below.

\section{Staples Mountain Gabbro}

Coughlan (1986) recognized five units in the Staples Mountain Gabbro, designated I to V from inferred bottom to top: I - gabbro, anorthositic gabbro, and olivine gabbro; II subophitic augite gabbro; III - interlayered norite and anorthosite; IV - unlayered augite gabbro and minor olivine gabbro; $\mathrm{V}$ - unlayered gabbronorite, with increased orthopyroxene and no olivine, in contrast to unit IV. She interpreted the pluton to be a layered sill-like body, formed by crystal fractionation processes; more details are available in Coughlan (1986).

\section{St. Stephen Gabbro}

Paktunc (1989) divided what he termed the St. Stephen Intrusion into ultramafic, olivine-bearing mafic, and mafic zones, and interpreted compositional variation and local crude layering to fractional crystallization. We instead include most of the mafic zone of Paktunc (1989) in the Calais Quartz Diorite, and the remainder of the St. Stephen Pluton is divided into four units: dunite, troctolite, olivine gabbro, and gabbro (Fig. 2). The pluton has crudely concentric zoning in map view, with the central dunite unit surrounded by the locally well layered troctolite unit, then the olivine gabbro unit, and finally the gabbro unit around the margin. Contacts between these units appear to be gradational, implying that they formed as a result of differentiation processes in a single parent magma. The St. Stephen Gabbro contains significant sulphide mineralization of potentially economic importance, especially for $\mathrm{Ni}$ and $\mathrm{Co}$ (Houston 1956; Kooiman 1996).

The dunite typically contains $95-100 \%$ olivine with minor plagioclase, pyroxene, and chromite, and has a coarse-grained adcumulate texture (Fig. 3a). It is partially serpentinized, and in the smaller satellite bodies, olivine has been completely replaced by serpentine and magnetite. Sulphide minerals appear to be concentrated in the serpentinized parts of the dunite, suggesting that they also may be secondary. With decreasing cumulus olivine and increasing cumulus plagioclase, the dunite grades into troctolite (Fig. $3 \mathrm{~b}$ ). Some parts of the troctolite consist of interlayered olivine-rich troctolite and anorthosite. Pyroxene, hornblende, and magnetite are minor components of the troctolite. With increasing amounts of pyroxene, the troctolite in turn grades to olivine gabbro (Fig. $3 c$ ), olivine gabbronorite, and anorthositic gabbro all included in the olivine gabbro unit of the pluton. In addition to olivine and plagioclase, both orthopyroxene and clinopyroxene are typically present, as well as varying amounts of amphibole and phlogopite, and accessory apatite, titanite, and zircon. The southwestern and southeastern parts of the pluton consist mainly of gabbro, in which large grains of clinopyroxene enclose plagioclase laths, and orthopyroxene is minor or absent (Fig. 3d).

Although both the St. Stephen and Staples Mountain plutons contain abundant olivine-bearing rocks, the Staples Mountain Gabbro appears to lack the ultramafic component that is present in the St. Stephen Gabbro, and the latter lacks

Fig. 3 (Facing page) Petrographic features of units of the MPS. Long dimension of all photomicrographs is $4 \mathrm{~mm}$; all except (e) are taken under crossed polars. (a) Photomicrograph of dunite from the St. Stephen Pluton showing olivine and interstitial plagioclase. (b) Photomicrograph of troctolite from the St. Stephen Pluton showing olivine, plagioclase, and minor clinopyroxene. (c) Photomicrograph of olivine gabbro from the St. Stephen Pluton, in which plagioclase and olivine are partially surrounded by clinopyroxene. (d) Photomicrograph of ophitic gabbro from the gabbro unit of the St. Stephen Pluton, showing clinopyroxene enclosing plagioclase. (e) Photomicrograph of quartz diorite from the Calais Quartz Diorite, in which plagioclase is partially enclosed by amphibole with relict cores of orthopyroxene. (f) Slabbed surface of a typical monzogranite sample from the Baring Granite, stained to enhance alkali feldspar (yellow), plagioclase (white), and quartz (grey) following Hutchinson (1974). (g) Photomicrograph of the same sample as in (f), showing alkali feldspar, zoned plagioclase, biotite, and quartz. (h) Photomicrograph of diorite from the Elliott Mountain Diorite, showing plagioclase, amphibole, and clinopyroxene. Photomicrographs (a) to (d) are reproduced from Gaskill (1999). 

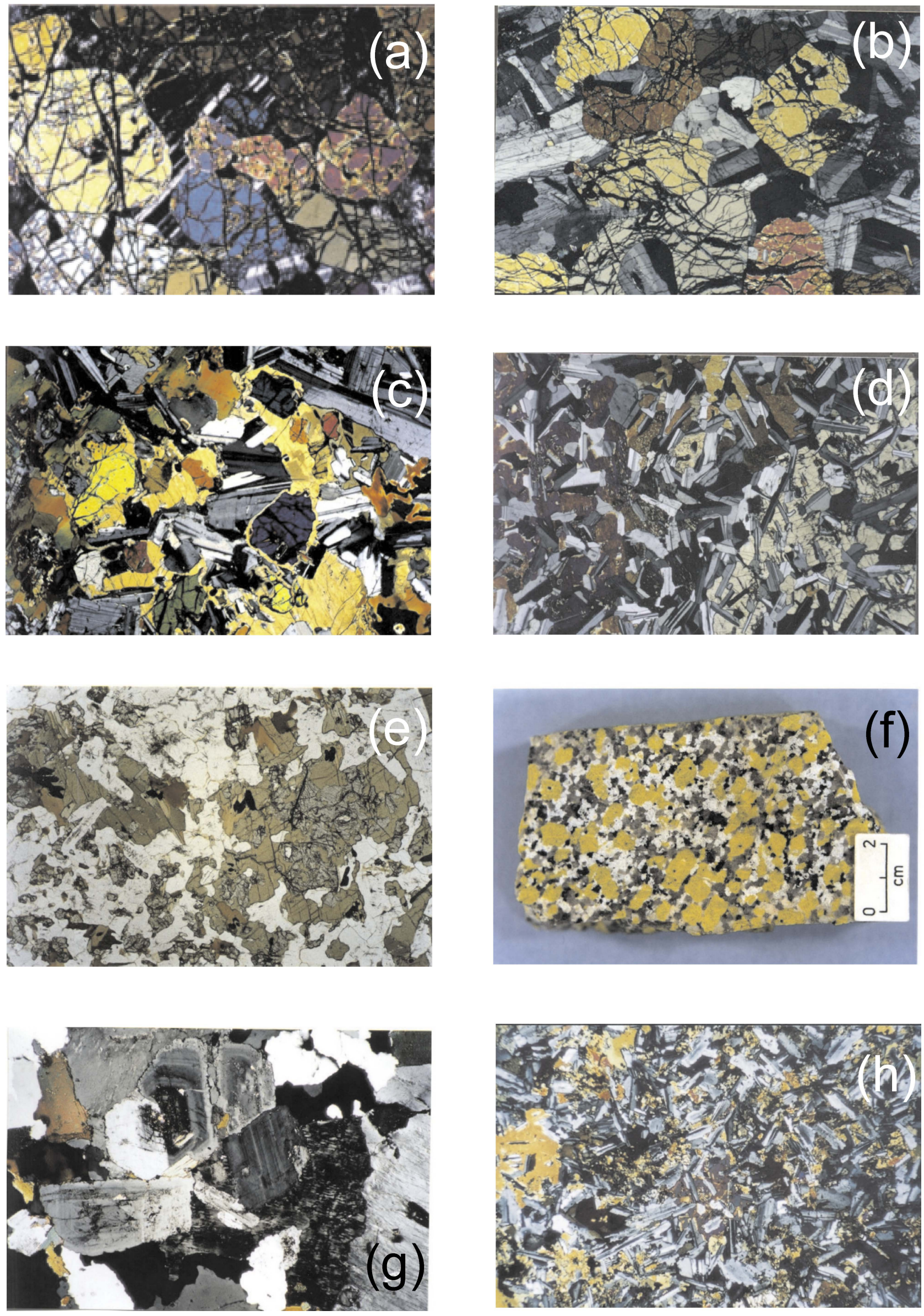
the aligned plagioclase grains that are characteristic of the Staples Mountain body, at least at the current levels of exposure. These differences may be related to the smaller size of the Staples Mountain body.

\section{Calais Quartz Diorite}

The Calais Quartz Diorite unit consists mainly of quartz diorite grading to diorite. The rocks are typically fine to medium grained with hypidiomorphic granular to locally ophitic texture involving amphibole and plagioclase (Fig. 3e). Two types of amphibole are present, an earlier generation of magnesiohornblende with greenish brown-brown-tan pleochroism and later pale green-green actinolitic hornblende. Most samples also contain augite and biotite. Interstitial quartz makes up 5 to $8 \%$ of the rock. Minor K-feldspar is present locally, and may reflect places where mixing occurred between mafic and granitic magmas. In some areas, generally near contacts with the Baring Granite unit, quartz diorite has hiatal porphyritic texture with plagioclase phenocrysts 2 to $4 \mathrm{~cm}$ in length, set in a fine-grained intersertal to intergranular matrix of augite, plagioclase, and quartz. Outcrop-scale areas of gabbro within the Calais Quartz Diorite unit may be xenolithic or mingled material from the Staples Mountain and St. Stephen plutons, although some may be younger intrusions, perhaps related to the Elliott Mountain Diorite.

\section{Baring Granite}

Typical granite of the Baring Granite unit is coarse-grained with hypidiomorphic sub-equigranular texture (Fig. 3f, g). Modal composition is mainly syenogranite to monzogranite, with quartz, plagioclase, and potassium feldspar present in approximately equal amounts, and biotite \pm hornblende forming approximately 6 to $8 \%$. Plagioclase locally mantles the potassium feldspar in rapakivi texture. Accessory phases include zircon, apatite, allanite, and titanite. Near the margins of the pluton, the granite contains numerous xenoliths, composed primarily of metasedimentary rocks from the St. Croix terrane in the west, as well as displaying the complex mingling relations with the Calais Quartz Diorite described by Hill and Abbott (1989), Jurinski (1990), Ludman and Hill (1990), and Hill (1991)

\section{Elliott Mountain Diorite}

The Elliott Mountain Diorite unit, although heterogeneous, consists mainly of diorite grading to quartz diorite. Typical diorite (Fig. 3h) is made up of plagioclase, hornblende, augite, orthopyroxene, quartz, magnetite, titanite, and apatite. Augite is typically interstitial to plagioclase, whereas orthopyroxene occurs as relict cores in hornblende. The diorite contains pillow-shaped bodies of fine-grained diorite (diabase of Abbott 1986), which appears to be of similar composition to the host diorite. They may have formed by disruption of early crystal-

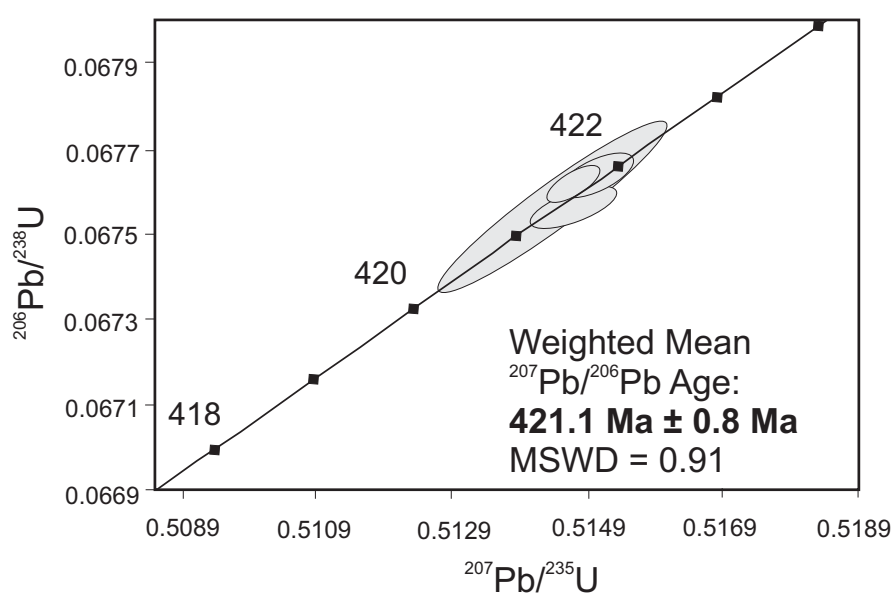

Fig. 4 Concordia diagram for four zircon fractions from Baring Granite sample SS00-124 (data from Table 2). Error on age is $2 \sigma$.

lized parts of the magma by subsequent magma movement. A swarm of northeast-southwest trending bodies tapering to dykes composed of blue-grey biotite-hornblende granodiorite is present throughout the Elliott Mountain diorite, as mapped by Abbott (1986). These dykes contain numerous angular blocks composed of diorite, and are likely to be related to one of the adjacent younger granitic plutons.

\section{Minor gabbroic and dioritic units}

The gabbro body in the vicinity of the Woodland Dump was described by Ludman and Hill (1990) to consist of olivine norite. Our sample (SS00-129; Fig. 2) consists of mediumgrained plagioclase, orthopyroxene, olivine, brown amphibole, and phlogopite, and is similar to samples from the olivine gabbro unit of the St. Stephen Gabbro. A mafic dyke-like body (SS00-108) sampled in the Baring Granite consists mainly of plagioclase, with minor quartz, K-feldspar, green-brown amphibole, clinopyroxene, and orthopyroxene.

\section{GEOCHRONOLOGY}

\section{U-Pb Dating}

Dated sample SS00-124 is a white, medium- to coarsegrained monzogranite, typical of the Baring Granite unit. Zircon grains were separated from a $20 \mathrm{~kg}$ sample in the geochronology laboratory at the Massachusetts Institute of Technology by standard techniques, abraded to obtain clean, unaltered grains, and dated using methodology as described by Schmitz and Bowring (2003). Two pale yellow, slender prisms (length:width $=2.8: 1$ ) with blunt terminations, as well as two 


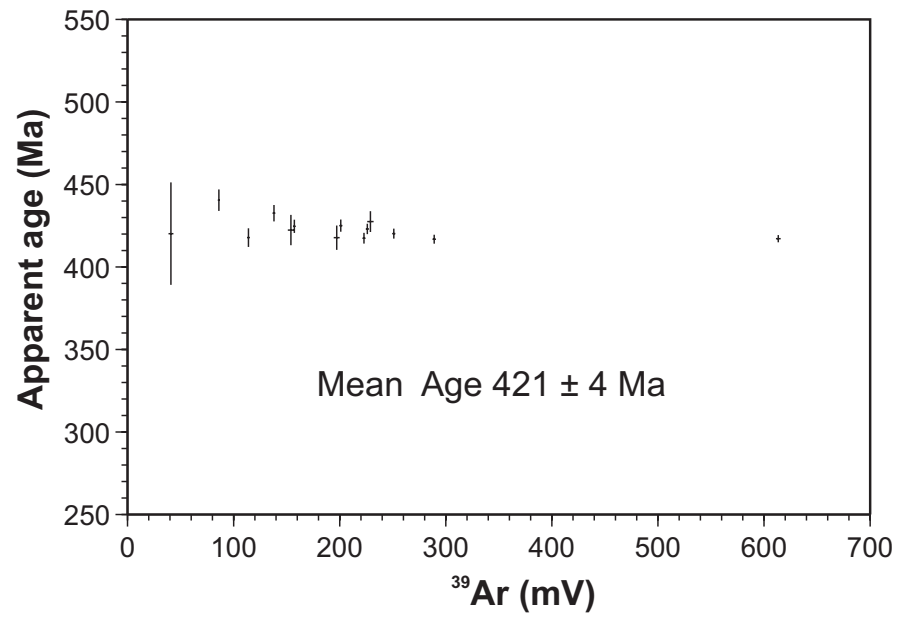

Fig. $5 .{ }^{40} \mathrm{Ar} /{ }^{39} \mathrm{Ar}$ ages for 14 spot analyses of phlogopite grains separated from sample SS98-36 from the St. Stephen Pluton (data from Table 3). Errors shown are $1 \sigma$, and do not include uncertainty in the J parameter. Age is a weighted mean based on ${ }^{39} \mathrm{Ar}$ and excluding spot 4 ; error is at $2 \sigma$, including $\mathrm{J}$ error.

fragments of such prisms, were analyzed (Table 2). All four fractions are concordant, yielding a precise crystallization age of $421.1 \pm 0.8 \mathrm{Ma}$ (Fig. 4 ), at $2 \sigma$ error.

This age is the same, within error, as the age of $423 \pm 3 \mathrm{Ma}$ obtained by the U-Pb (zircon) method for the Utopia Granite (M.L. Bevier, 2001, personal communication to S.M. Barr). The age is similar also to ages of various other plutons of the coastal Maine magmatic province (Fig. 1), such as the South Penobscot Pluton (419 $\pm 2 \mathrm{Ma}$, U-Pb, zircon; Stewart et al. 2001), Spruce Head Pluton (421 $\pm 1 \mathrm{Ma}$, U-Pb, zircon; Tucker et al. 2001), Cadillac Mountain intrusive complex (424 \pm 2 and $419 \pm 2 \mathrm{Ma}$, U-Pb, zircon; Seaman et al. 1995), and Sedgwick Pluton (419.5 $\pm 1 \mathrm{Ma}$, U-Pb, zircon; Stewart et al. 2001).

\section{${ }^{40} \mathrm{Ar} /{ }^{39} \mathrm{Ar}$ Dating}

Sample SS98-36 from the olivine gabbro unit of the St. Stephen Gabbro (location shown on Fig. 2) contained relatively large and abundant interstitial phlogopite suitable for ${ }^{40} \mathrm{Ar} /{ }^{39} \mathrm{Ar}$ dating. Phlogopite grains were picked from the crushed sample using tweezers under a binocular microscope. For irradiation in the McMaster University nuclear reactor (in Hamilton, Ontario), the selected grains were placed individually into holes machined in aluminum disks. The flux monitor was the hornblende standard, MMhb-1 (assumed age $=520$ $\mathrm{Ma}$; Samson and Alexander 1987). Laser analyses were made with a Nd-YAG system operated in continuous mode with the beam expanded to approximately cover the grain. Power was then increased in a series of steps until complete fusion was achieved. Isotopic analyses were made using a VG 3600 mass spectrometer.

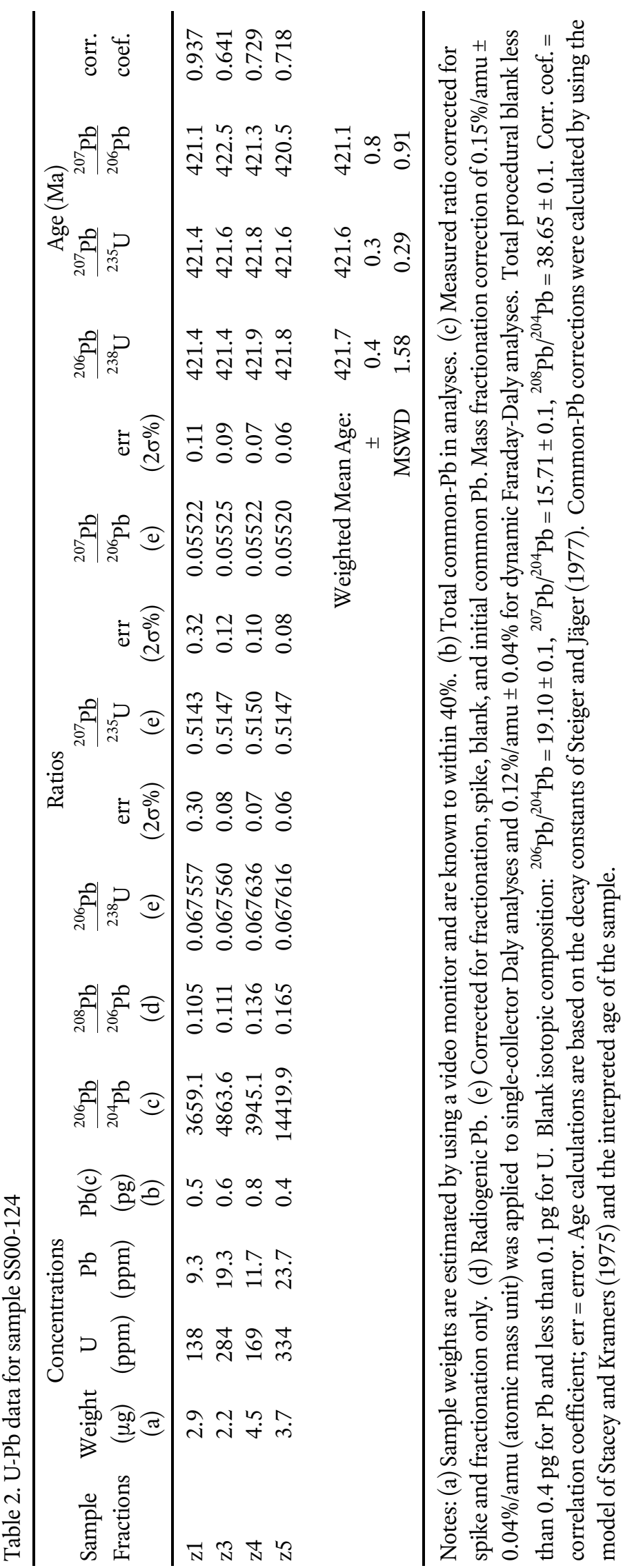


The single grain ages are plotted against ${ }^{39} \mathrm{Ar}$ abundance for each analysed grain (Fig. 5). With one exception (Spot 5 ), no significant differences in apparent age were observed among the fourteen grains. The mean age is $421 \pm 4 \mathrm{Ma}(2 \sigma$ uncertainty, which includes the estimated error in the irradiation parameter, J). This age is interpreted to be the time of cooling of phlogopite through its argon closure temperature (ca. $300-400^{\circ} \mathrm{C}, \mathrm{McDougall}$ and Harrison 1999), and likely approximates the time of crystallization of the gabbro. It is similar within error to a previously reported amphibole KAr age of $418 \mathrm{Ma}$ (Wanless et al. 1973) from the St. Stephen Gabbro. However, it is significantly older than the biotite (presumably phlogopite) K-Ar age from the same pluton (Wanless et al. 1973). It is also similar to the previously reported ${ }^{40} \mathrm{Ar} /$

${ }^{39} \mathrm{Ar}$ age of $422.7 \pm 3 \mathrm{Ma}$ reported for hornblende from the Pocomoonshine Gabbro-Diorite (West et al., 1992).

\section{GEOCHEMISTRY}

\section{Introduction}

Although complex mingling, mixing, and gradational contacts characterize relations in the MPS, as described above, heterogeneous rocks were avoided in sampling for geochemistry in this study. We focused on homogeneous-looking samples that appeared characteristic of the main units of the MPS (Table 4). Some of the samples analysed as part of this study ( $\mathrm{MH}$ designation in Table 4) were obtained from the collection of M. Hill and analyzed as part of the present project. The geochemical data of Gaskill (1999) were integrated into our study after a re-examination of his thin sections and samples. However, we have not included the large chemical data base of Paktunc (1989) because of uncertainty in locations and petrographic features of the analyzed samples. As demonstrated by McLaughlin (2003), they do not significantly change the conclusions of this study.

Also included in Table 4 are data for the Bocabec Pluton. The major element data for these samples are from Fyffe (1971), and trace element analyses were obtained from the same sample powders as part of the present study. In addition, four other granitic samples from the thesis collection of Fyffe (1971) were analyzed by K. Thorne and D. Lentz, and those unpublished data are included, with permission, in Table 3. Additional data from Ludman and Hill (1990), Coughlin (1986), McLeod (1990) (including data listed in his Appendix 4), and Thorne and Lentz (2001) are included on the diagrams, but not listed in Table 4 .

\section{Major element compositions}

Plots against $\mathrm{SiO}_{2}$ are used to illustrate chemical characteristics of the units of the MPS (Fig. 6). Dioritic and gabbroic samples from the Staples Mountain, St. Stephen, and Elliott Mountain plutons all have less than about $50 \% \mathrm{SiO}_{2}$, but show differences in other major element oxides. The Staples Mountain samples show a wide range in most elements, consistent with their wide range in rock types and cumulate features as described by Coughlin (1986). Their most distinctive characteristics compared to the dioritic and gabbroic samples are

Table 3. ${ }^{40} \mathrm{Ar} /{ }^{39} \mathrm{Ar}$ data for sample SS98-36.

\begin{tabular}{clccccccc}
\hline Spot & Code & mV 39 & $\begin{array}{c}\text { Age } \pm 1 \sigma \\
(\mathrm{Ma})\end{array}$ & $\%$ ATM & $\frac{{ }^{37} \mathrm{Ar}}{\frac{39}{39}}$ & $\frac{{ }^{36} \mathrm{Ar}}{40} \mathrm{Ar}$ & $\frac{{ }^{39} \mathrm{Ar}}{40} \mathrm{Ar}$ & $\%$ IIC \\
\hline 1 & C66-3-1 & 197.1 & $417.7 \pm 7.3$ & 1.2 & 1.17 & 0.000041 & 0.009593 & 0.16 \\
2 & C66-7-2 & 154 & $422.3 \pm 9.1$ & 0.8 & 1.19 & 0.000030 & 0.009504 & 0.16 \\
3 & C66-2-2 & 228.9 & $427.5 \pm 6.2$ & 0 & 0.38 & 0.000001 & 0.009460 & 0.05 \\
4 & C66-6-1 & 40.8 & $420.2 \pm 31$ & 6 & 3.47 & 0.000204 & 0.009041 & 0.47 \\
5 & C66-11-2 & 86 & $440.4 \pm 6.5$ & 0.6 & 1.13 & 0.000023 & 0.009092 & 0.15 \\
6 & C66-14-2 & 200.9 & $425.0 \pm 3.7$ & 2.6 & 0.23 & 0.000089 & 0.009276 & 0.03 \\
7 & C66-4-2 & 250.9 & $420.2 \pm 3$ & 1.6 & 0.07 & 0.000054 & 0.009496 & 0.01 \\
8 & C66-5-2 & 157.2 & $424.6 \pm 4$ & 0.6 & 0.06 & 0.000021 & 0.009478 & 0 \\
9 & C66-1-2 & 613.4 & $417.1 \pm 2.1$ & 1.4 & 0.3 & 0.000048 & 0.009595 & 0.04 \\
10 & C66-8-1 & 289 & $416.8 \pm 2.7$ & 1.6 & 0.12 & 0.000054 & 0.009584 & 0.01 \\
11 & C66-9-1 & 222.8 & $417.4 \pm 3.2$ & 2.3 & 0.36 & 0.000080 & 0.009494 & 0.05 \\
12 & C66-10-2 & 138 & $432.6 \pm 4.9$ & 5.5 & 0.8 & 0.000186 & 0.008826 & 0.1 \\
13 & C66-12-2 & 226 & $423.0 \pm 3.1$ & 0.4 & 0.53 & 0.000014 & 0.009540 & 0.07 \\
14 & C66-13-2 & 113.9 & $417.8 \pm 5.6$ & 6.6 & 0.99 & 0.000224 & 0.009068 & 0.13 \\
\hline
\end{tabular}

Mean age $=421 \pm 4 \mathrm{Ma}(2 \sigma$ uncertainty, including error in $\mathrm{J})$. Grain 4 omitted from mean age

calculation because probably polymineralic. $\mathrm{J}=0.002533 \pm 0.000025(0.9 \%) .{ }^{37} \mathrm{Ar} /{ }^{39} \mathrm{Ar},{ }^{36} \mathrm{Ar} /{ }^{40} \mathrm{Ar}$, and ${ }^{39} \mathrm{Ar} /{ }^{40} \mathrm{Ar}$ are corrected for mass spectrometer discrimination, interfering isotopes, and system blanks. $\%$ IIC - Interfering isotopes correction. 

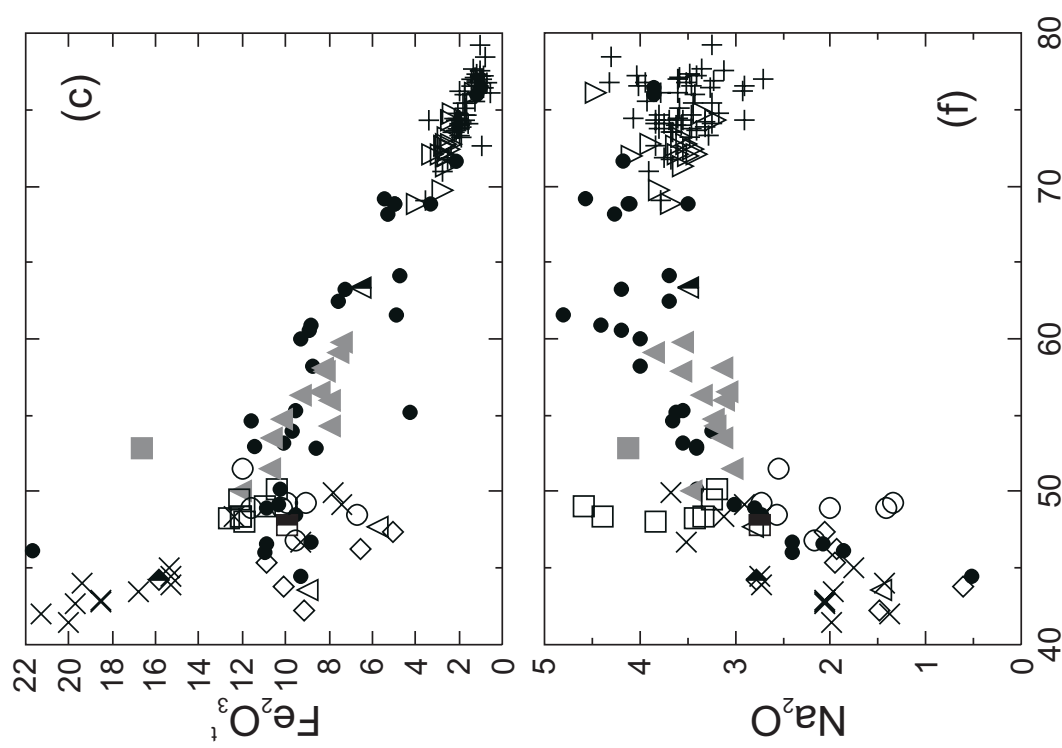

$\widehat{0} \quad \widehat{10}$

$\stackrel{\infty}{\frac{0}{2}} \stackrel{\text { II }}{=}$

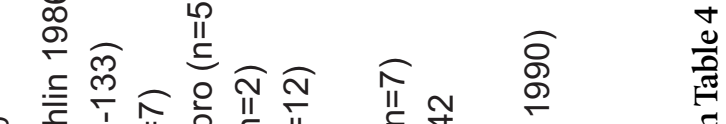

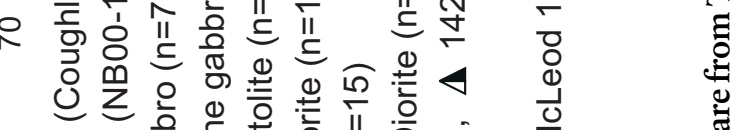

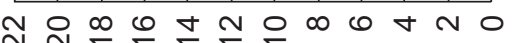

$$
{ }_{1}^{\varepsilon} \mathrm{O}^{2} \partial_{\exists}
$$

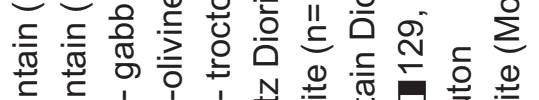

旁焉

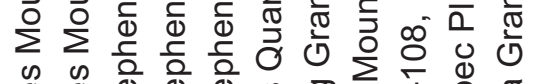

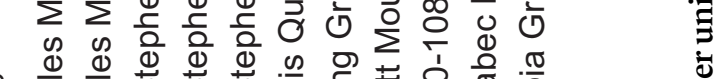

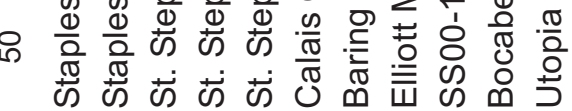

$\times \diamond 0 \diamond \triangleleft<\triangleright \square \square \bullet+$
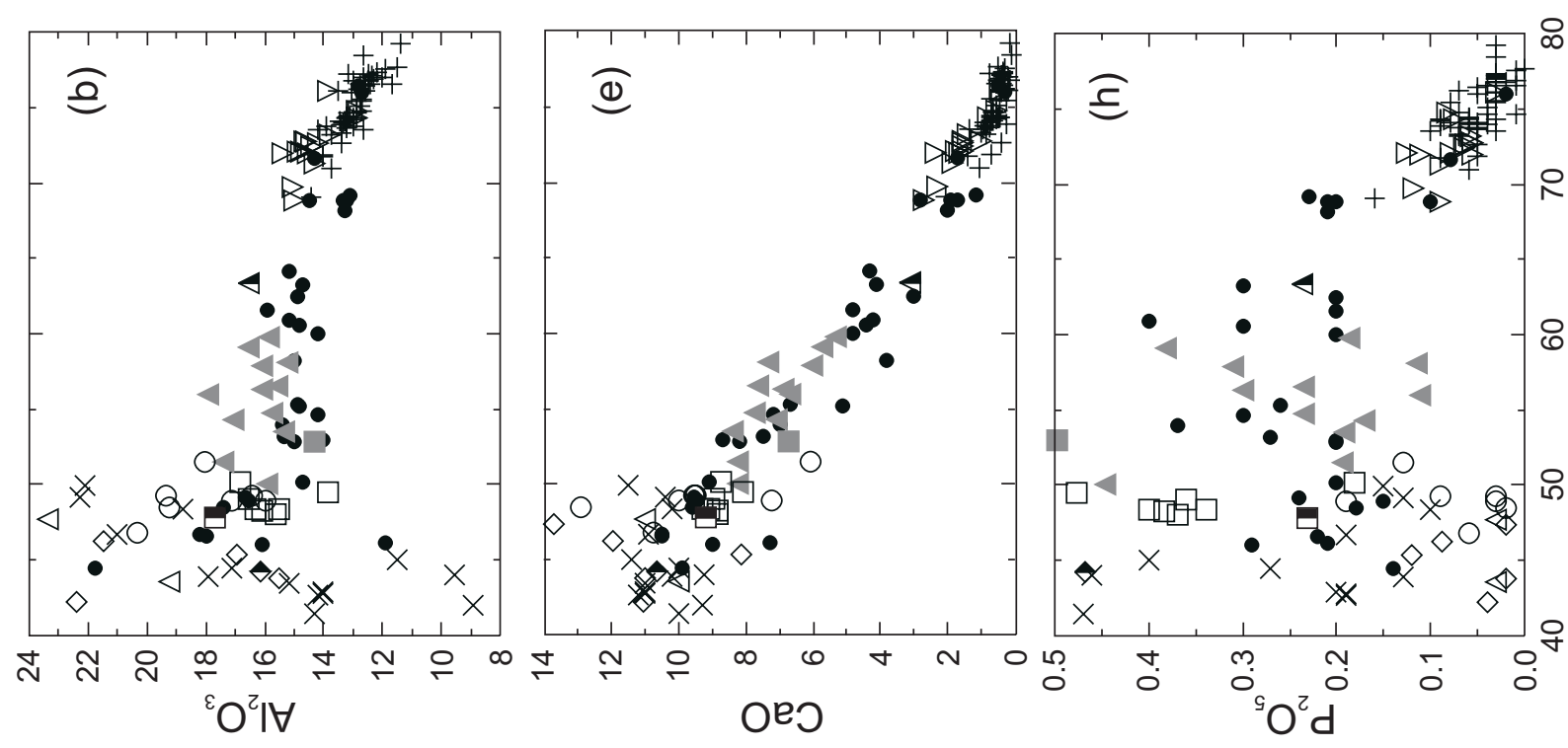

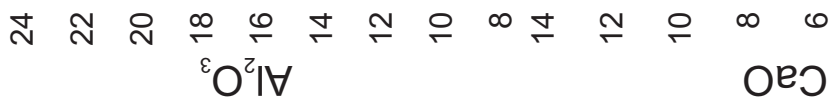
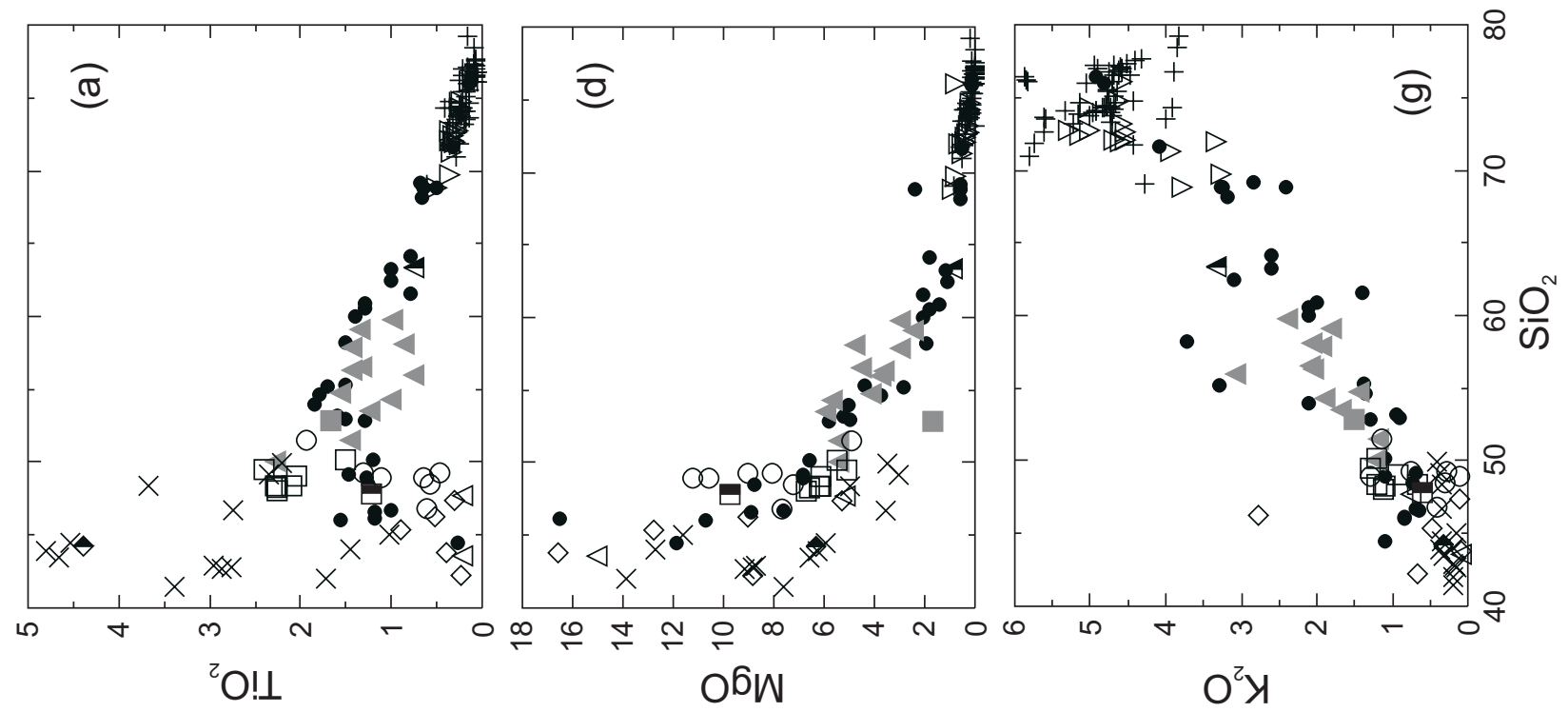

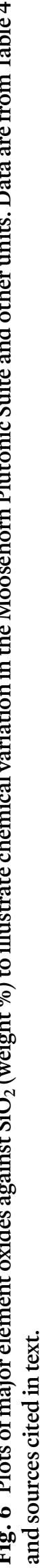




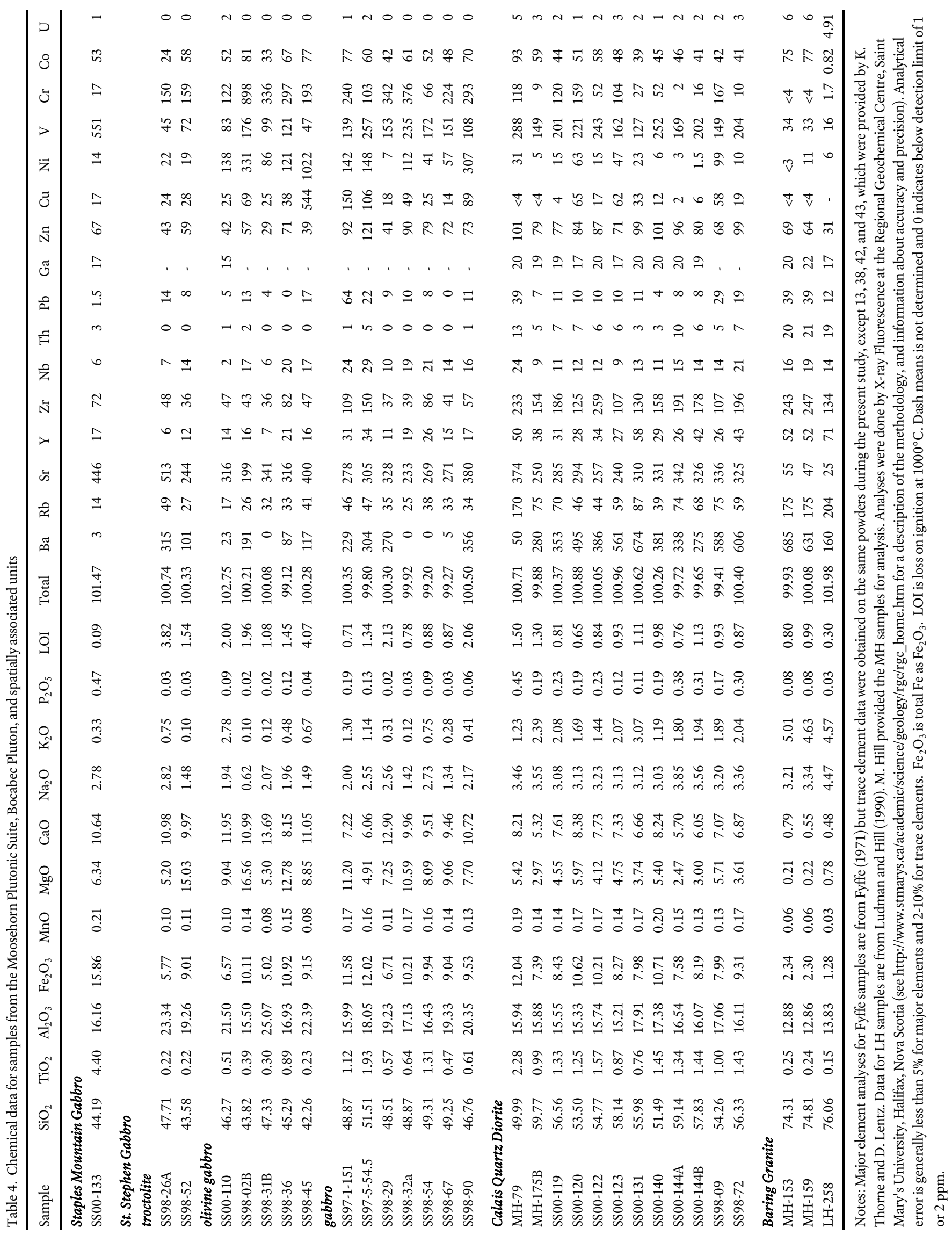




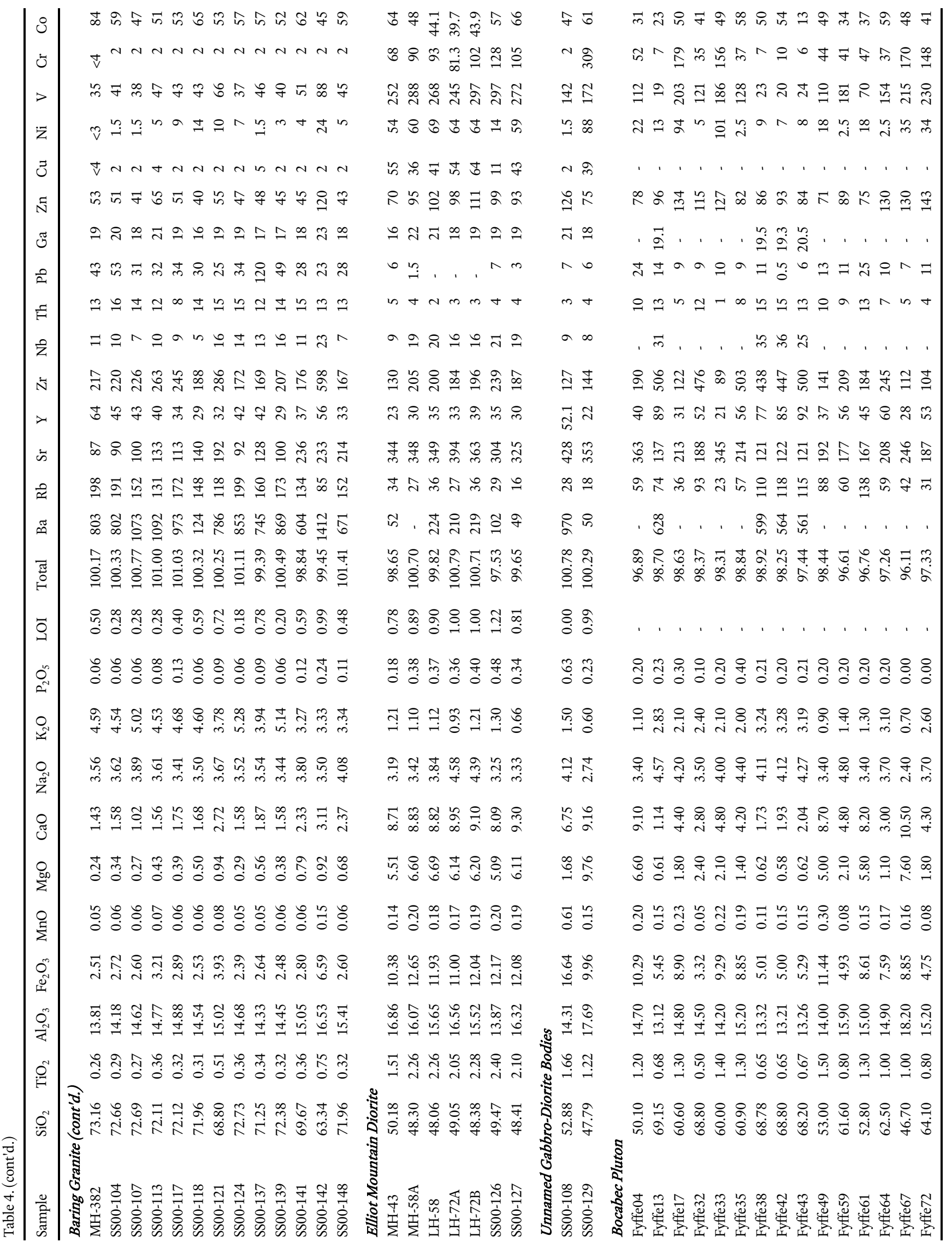


their high Fe and Ti contents (Fig. 6a, c). The Elliott Mountain samples tend to overlap in composition with gabbro from the St. Stephen Gabbro, but have higher $\mathrm{TiO}_{2}, \mathrm{Na}_{2} \mathrm{O}$, and $\mathrm{P}_{2} \mathrm{O}_{5}$ and lower $\mathrm{MgO}$ contents (Fig. 6a, f, h, d). Compared to samples from the gabbro unit in the St. Stephen Gabbro, the olivine gabbro and troctolite samples have lower $\mathrm{SiO}_{2}$, but also a trend toward lower $\mathrm{TiO}_{2}, \mathrm{Na}_{2} \mathrm{O}$, and $\mathrm{P}_{2} \mathrm{O}_{5}$ contents. Variations in $\mathrm{Al}_{2} \mathrm{O}_{3}, \mathrm{Fe}_{2} \mathrm{O}_{3}{ }^{\mathrm{t}}, \mathrm{MgO}$, and $\mathrm{CaO}$ are consistent with the occurrence of cumulate textures in most of the analysed samples, and can be accounted for by olivine, pyroxene, and plagioclase separation or accumulation. In general, the trend from the more mafic samples of the St. Stephen Gabbro to the higher $\mathrm{SiO}_{2}$ samples of the Calais Quartz Diorite can be explained by fractionation of plagioclase, olivine, and pyroxene, and it is likely that these plutons are co-magmatic. In comparison, both the Staples Mountain Gabbro and Elliott Mountain Diorite units show differences in major element compositions which suggest that they are not genetically related to the St. Stephen and Calais plutons. Sample SS00-108 from a gabbroic dyke(?) in the Baring Granite has higher $\mathrm{SiO}_{2}$ than any samples analyzed from the Staples Mountain Gabbro, but also shows high $\mathrm{Fe}_{2} \mathrm{O}_{3}$ and low $\mathrm{MgO}$, as well as high $\mathrm{Na}_{2} \mathrm{O}$ and $\mathrm{P}_{2} \mathrm{O}_{5}$ contents (Fig. 6f, h). In contrast, sample SS00-129 from the Woodland Dump gabbro of Ludman and Hill (1990) is similar to samples of similar $\mathrm{SiO}_{2}$ content from the St. Stephen Gabbro.

With one exception (granodiorite SS00-142), analyzed samples from the Baring Granite are all of granite composition, and have high $\mathrm{SiO}_{2}$ contents (more than 68\%), and correspondingly low contents of other major elements except $\mathrm{Na}_{2} \mathrm{O}$ and $\mathrm{K}_{2} \mathrm{O}$ (Fig. 6). These chemical features are consistent with the high contents of sodic plagioclase, K-feldspar, and quartz and low abundance of ferromagnesian minerals in the samples. Chemical similarity between the Baring Granite and the Utopia Granite (data from McLeod 1990) is apparent, although the compositional range reported for the Utopia Granite extends to higher $\mathrm{SiO}_{2}$ content.

Data from the Bocabec Pluton are also shown on Fig. 6. As described in detail by Fyffe (1971) and McLeod (1990), these samples represent the mafic and felsic components in the suite, and also the intermediate units that were inferred to have formed by mixing and hybridization between the mafic and felsic magmas. The range of compositions encompasses most of the samples from the Calais Quartz Diorite, as well as the gabbro unit of the St. Stephen Gabbro, thus supporting their co-genetic relationship. In contrast, the Staples Mountain and Elliott Mountain samples generally lie outside the Bocabec trend, implying that they are not closely linked to the other mafic magmas. The data also show that the granitic component of the Bocabec Pluton is chemically similar to the Baring Granite, and support the interpretation (Fyffe 1971; McLeod 1990) that the intermediate samples formed by a mixing process. Intermediate sample (SS00-142) from the MPS is chemically similar to intermediate samples from the Bocabec Pluton, suggesting that it may have had a similar origin, as a result of mixing between Baring Granite and Calais Quartz Diorite magmas.

\section{Trace element compositions}

Trace element data are more limited than major element data, and are mainly for samples from the present study (Table 4). Trace elements are available for only one sample from Staples Mountain Gabbro and variable numbers of samples from the Bocabec Pluton and Utopia Granite, depending on the element. Trends in Rb, Sr, and Ba within the mafic and felsic sample sets are generally consistent with feldspar fractionation (Figs. 7a-c). Gabbroic samples have mainly low $\mathrm{Rb}$ and $\mathrm{Ba}$, and high Sr, whereas the Calais Quartz Diorite generally has less $\mathrm{Sr}$ and more $\mathrm{Rb}$ and $\mathrm{Ba}$. Some Utopia Granite samples and one Baring Granite sample have high $\mathrm{Rb}$ and low $\mathrm{Ba}$, indicative of a highly evolved composition in which Ba has been partitioned into and removed with K-feldspar (Fig. 6g). However, overall, the Baring Granite is characterized by high Ba content (up to almost $1100 \mathrm{ppm}$ ).

Elements $\mathrm{Zr}, \mathrm{Nb}, \mathrm{Y}$, and $\mathrm{V}$ display wide variation and few trends on silica variation diagrams (Figs. 8a-d), related to the control of these elements by the abundance of mainly pyroxene and magnetite (e.g., Miyashiro and Shido 1975; Pearce and Norry 1979) which vary widely in the dioritic and gabbroic samples. The Utopia Granite overlaps the composition of the Baring Granite, but generally has higher $\mathrm{Nb}$ and $\mathrm{Y}$, and lower $\mathrm{Zr}$ (Figs. 8a-c). Some of the intermediate to granitic Bocabec Pluton samples have elevated $\mathrm{Zr}, \mathrm{Nb}$, and $\mathrm{Y}$, and low V (Fig. 8). High $\mathrm{Zr}$ content in intermediate samples may represent the build-up of that element in the magma prior to onset of zircon crystallization.

$\mathrm{Ni}$ and $\mathrm{Cr}$ show wide spread in the gabbroic and dioritic samples (Figs. 9a, b) related to variations in olivine and pyroxene contents. The Staples Mountain Gabbro sample (NB00133 ) is low in both elements compared to most St. Stephen Gabbro samples, further support for their lack of genetic relationship. $\mathrm{Cu}$ and $\mathrm{Co}$ also display a wide range in gabbroic to intermediate samples, with a few high values up to 150 and nearly 100 ppm, respectively (Figs. 9c, d). Ni, Cr, and Cu are low in all the granitic samples, but Co contents are high in the Baring Granite compared to most granitic Bocabec Pluton and Utopia Granite samples. $\mathrm{Pb}$ and $\mathrm{Zn}$ also differ between the Baring and Utopia granites, being generally higher in the Baring samples (Figs. 9e, f). Zn contents are highest in the intermediate rocks.

\section{Chemical affinity and tectonic setting}

Interpretation of chemical affinity and tectonic setting for units of the MPS is somewhat ambiguous, as illustrated by representative, commonly used diagrams in Fig. 10. With the exception of the Staples Mountain and Woodland Dump samples, which appear tholeiitic, gabbroic and dioritic samples show little iron enrichment, and calc-alkaline affinity is suggested (Fig. 10a). Most samples have low $\mathrm{Nb} / \mathrm{Y}$ ratios indicative of subalkalic affinity, although some St. Stephen and Bocabec samples plot in alkalic fields (Fig. 10b). Alkalic affinity is not supported by the V-Ti diagram (Fig. 10c), which suggests with- 

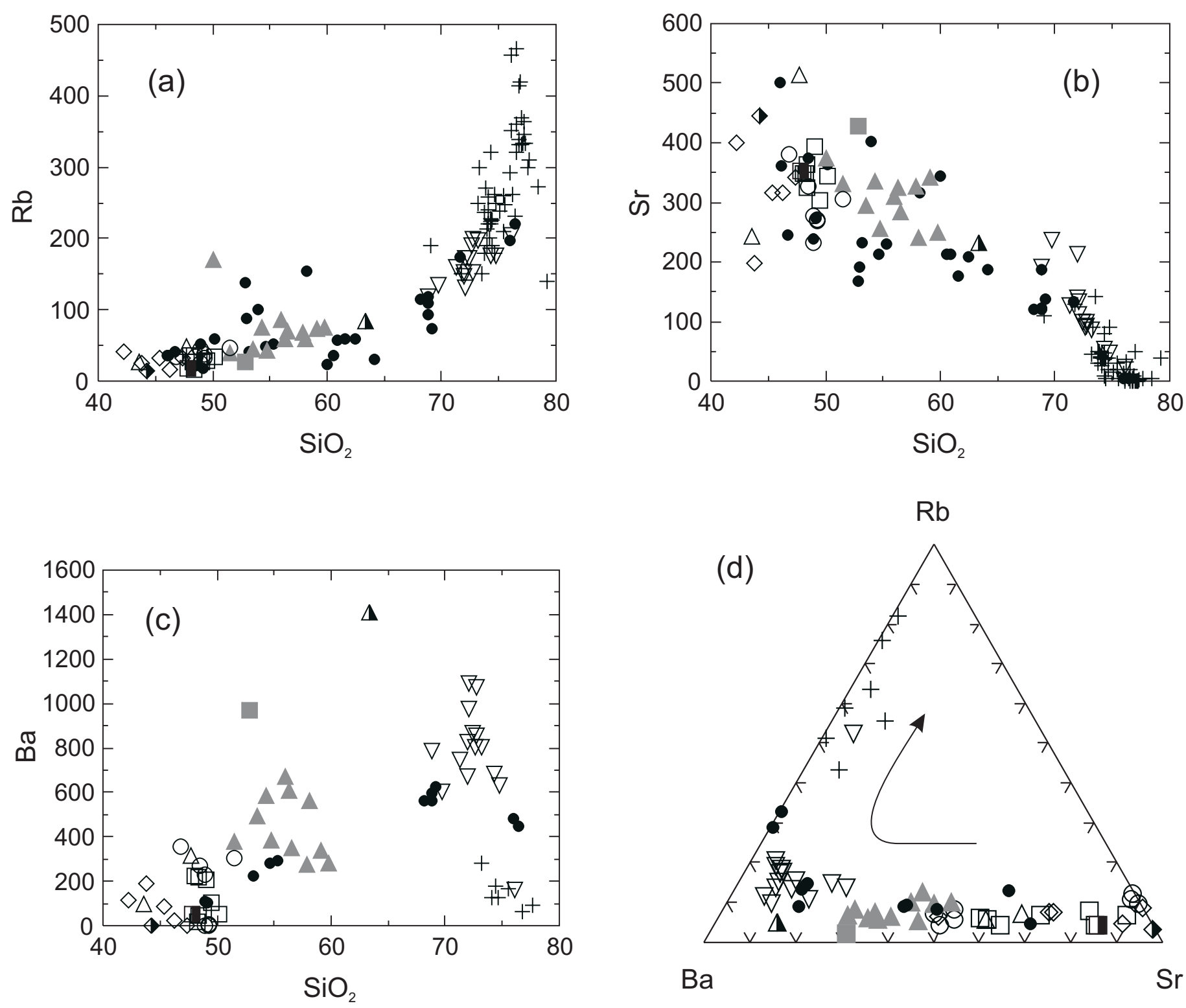

$\mathrm{Ba}$

$\mathrm{Sr}$

Fig. 7 Plots of (a) $\mathrm{Rb}$, (b) Sr, and (c) $\mathrm{Ba}$ (in ppm) against $\mathrm{SiO}_{2}$ (in weight \%), and (d) $\mathrm{Rb}$-Sr-Ba to illustrate chemical variation in the Moosehorn Plutonic Suite and other units. Arrow on (d) indicates granitoid evolutionary trend from El Bouseily and El Sokkary (1975). Data are from Table 4 and sources cited in text. Symbols are as in Fig. 6.

in-plate tholeiitic character for mafic samples. On the other hand, the Ti-Zr-Y diagram suggests calc-alkaline ( $\operatorname{arc})$ setting (Fig. 10d).

Granitic samples from the Baring Granite have lower Y and $\mathrm{Nb}$ contents, consistent with origin in a volcanic arc setting, whereas granitic samples from the Bocabec Pluton and Utopia Granite are generally more evolved and plot mainly in the within-plate granite field (Fig. 10e). Elevated $\mathrm{Zr}$ and Ga/Al ratio suggest A-type characteristics for these samples (Fig. 10f).

\section{Rare-earth elements}

Rare-earth element (REE) data were obtained for 15 samples from the MPS during the present study (Table 5).
Additional REE data for the MPS were taken from Ludman and Hill (1990) and data for the Bocabec pluton and Utopia Granite are from McLeod (1990). Some of the data from McLeod (1990) show erratic features that suggest analytical error, but the overall patterns are consistent enough to enable comparison with the MPS.

In comparison with the other units, the St. Stephen gabbro has low REE abundance and a relatively flat REE pattern (Fig. 11a). The positive Eu anomalies suggest plagioclase accumulation. The sample with highest REE abundance shows some enrichment in light REE relative to heavy REE, and the pattern is very similar to that of the Calais Quartz Diorite sample with lowest REE abundance. The samples from the Calais Quartz Diorite show parallel chondrite-normalized patterns, with a 

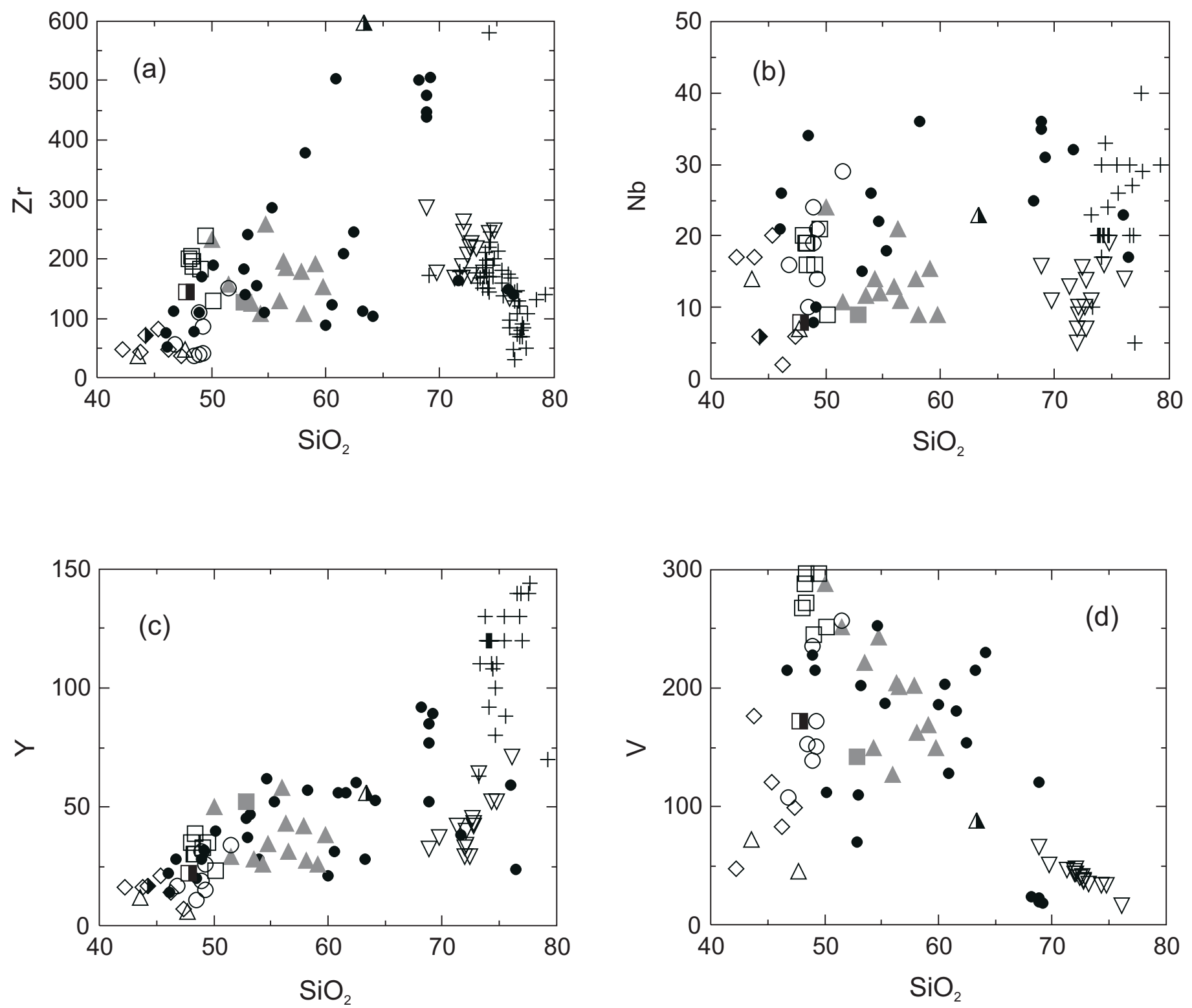

Fig. 8. Plots of (a) Zr, (b) $\mathrm{Nb},(\mathrm{c}) \mathrm{Y}$, and (d) V (in ppm) against $\mathrm{SiO}_{2}$ (in weight \%) to illustrate chemical variation in the Moosehorn Plutonic Suite and other units. Data are from Table 4 and sources cited in text. Symbols are as in Fig. 6.

change from a slight positive to a slight negative Eu anomaly with increasing REE abundance and increasing $\mathrm{SiO}_{2}$ content.

Mafic samples from the Bocabec Pluton display patterns similar to the Calais Quartz Diorite (Fig. 11b). However, an intermediate sample with over $58 \% \mathrm{SiO}_{2}$ has higher REE abundances and a pattern more similar to those of the Baring Granite samples (Fig. 11c). Three samples from the Elliot Mountain Diorite (Fig. 11c), all from Ludman and Hill (1990) are similar to the Calais Quartz Diorite, but do not show the small negative $\mathrm{Eu}$ anomalies that characterize the Calais samples.

Samples from the Baring Granite, Utopia Granite, and granite in the Bocabec Pluton all show strong negative Eu anomalies that could be explained by feldspar fractionation (Fig. 11c, e). They are most pronounced in the Utopia Granite, consistent with its more evolved character (e.g., Fig. 7e). However, in general the REE patterns are indicative of similar and related origins for these units.

Gabbro dyke(?) sample SS00-108 in the Baring Granite has high total REE abundance and a positive Eu anomaly (Fig. 11d). The high REE content, light REE enrichment compared to heavy REE, and strong positive Eu anomaly set it apart from other samples. It may be related to the Staples Mountain Gabbro, as suggested by some of its other chemical features, but no REE data are yet available from Staples Mountain for comparison. 

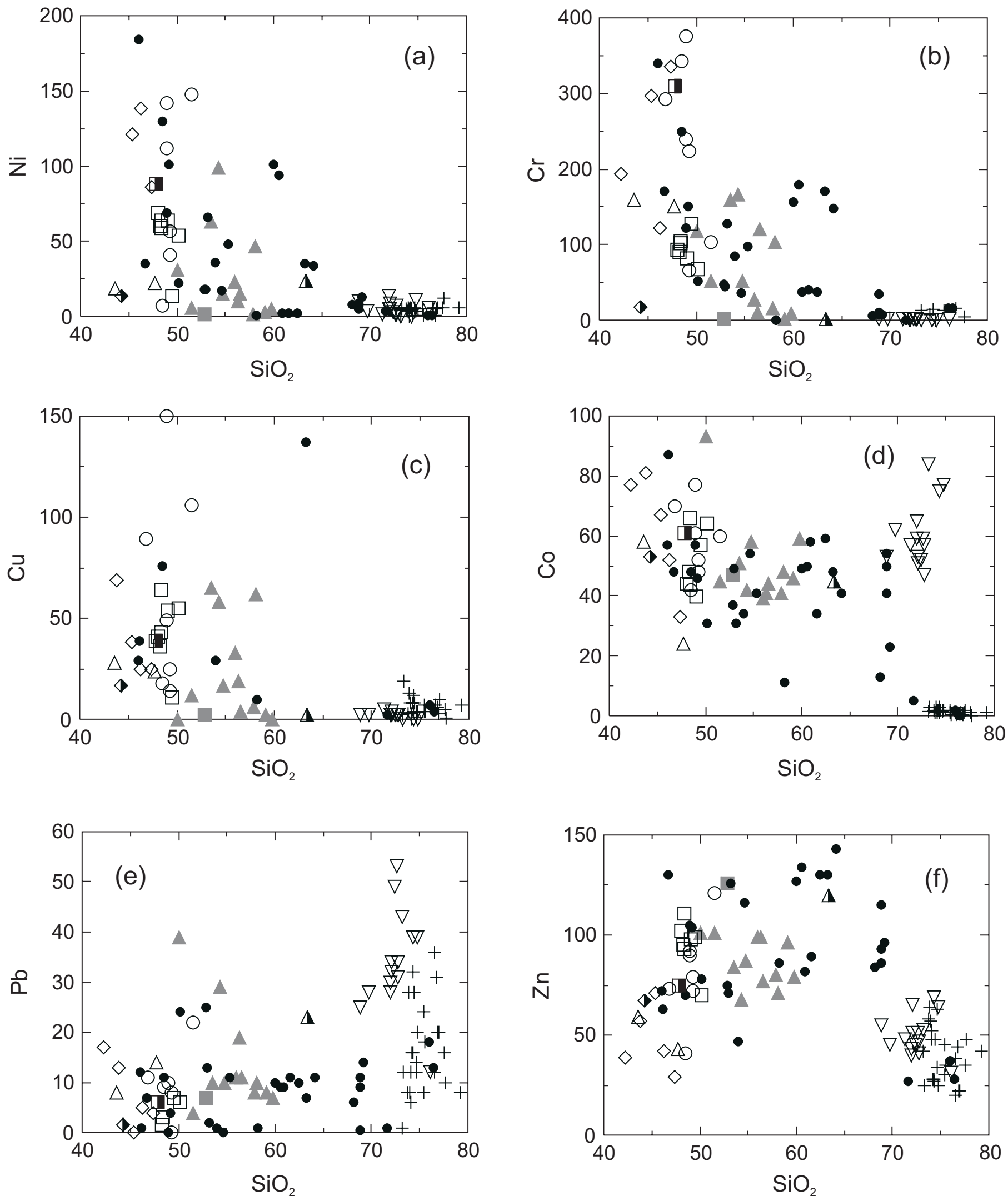

Fig. 9 Plots of (a) $\mathrm{Ni},(\mathrm{b}) \mathrm{Cr},(\mathrm{c}) \mathrm{Cu},(\mathrm{d}) \mathrm{Co},(\mathrm{e}) \mathrm{Pb}$, and (f) $\mathrm{Zn}$ (in ppm) against $\mathrm{SiO}_{2}$ (in weight \%) to illustrate chemical variation in the Moosehorn Plutonic Suite and other units. Data are from Table 4 and sources cited in text. Symbols are as in Fig. 6. 

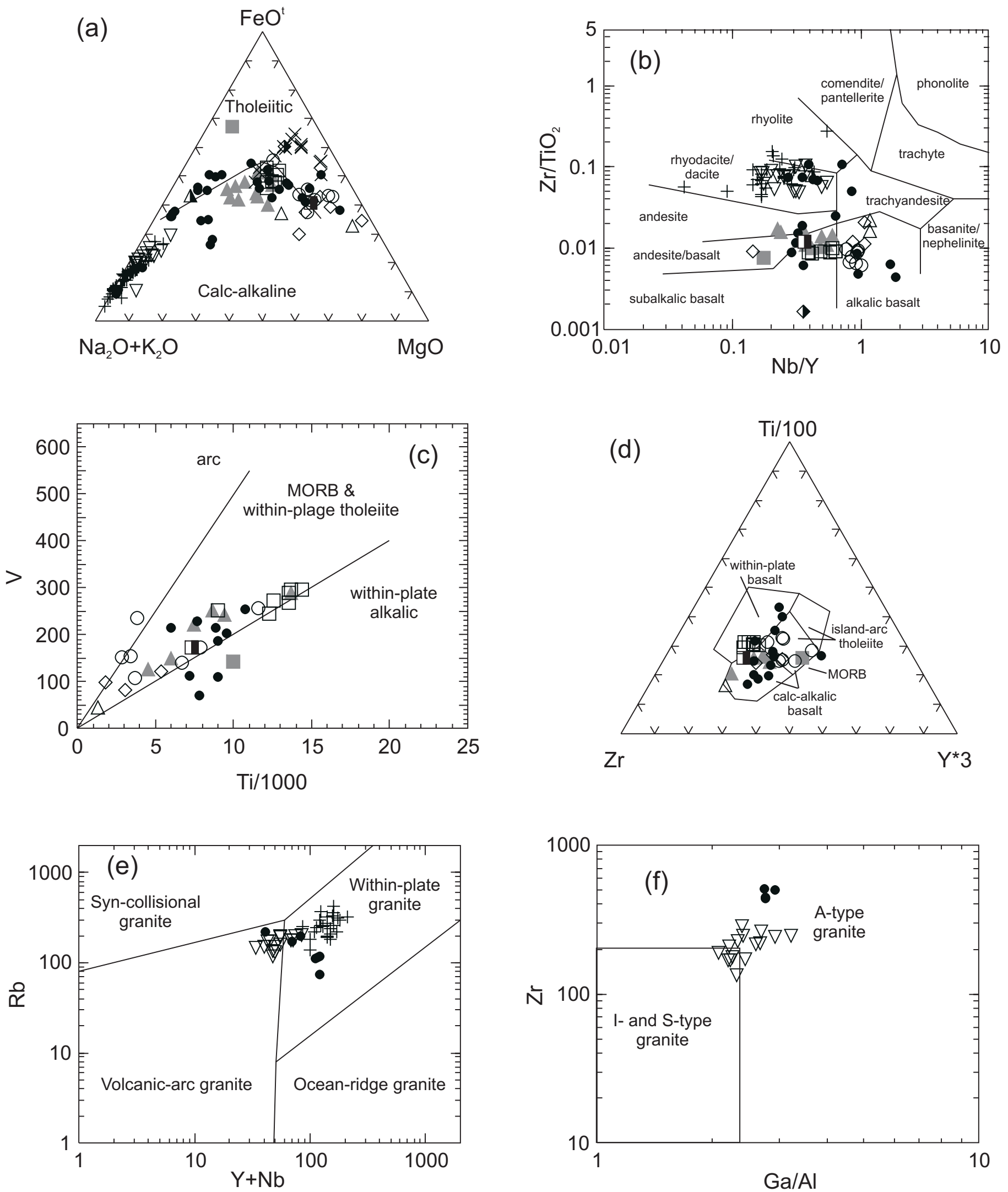

Fig. 10 Diagrams to illustrate chemical affinity and tectonic setting of the Moosehorn Plutonic Suite and other units. Data are from Table 4 and sources cited in text. Fields are from (a) Irvine and Baragar (1971), (b) Winchester and Floyd (1977), (c) Shervais (1982); (d) Pearce and Cann (1973); (e) Pearce et al. (1984), and (f) Whalen et al. (1987). Symbols are as in Fig. 6. 

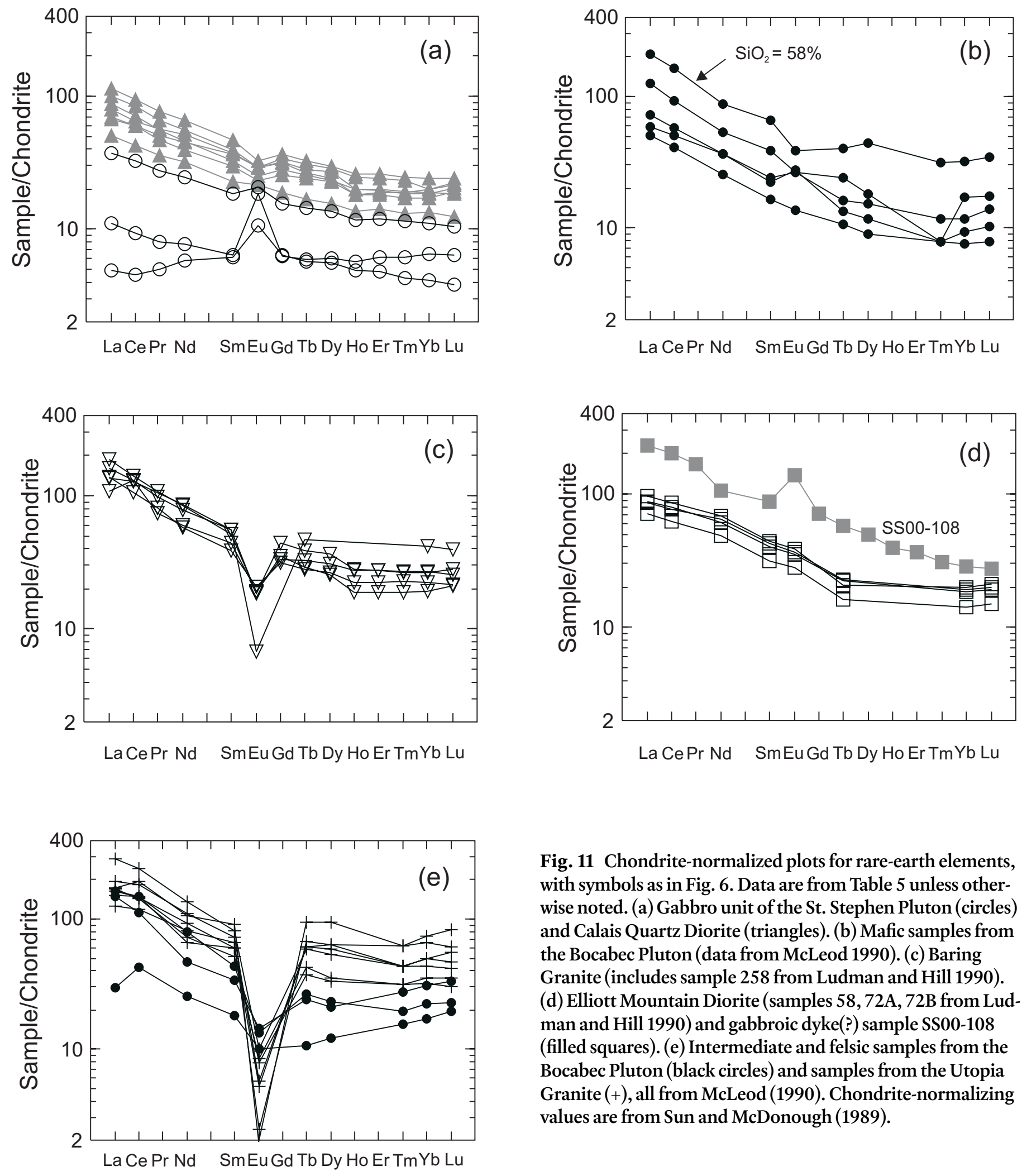

Fig. 11 Chondrite-normalized plots for rare-earth elements, with symbols as in Fig. 6. Data are from Table 5 unless otherwise noted. (a) Gabbro unit of the St. Stephen Pluton (circles) and Calais Quartz Diorite (triangles). (b) Mafic samples from the Bocabec Pluton (data from McLeod 1990). (c) Baring Granite (includes sample 258 from Ludman and Hill 1990). (d) Elliott Mountain Diorite (samples 58, 72A, 72B from Ludman and Hill 1990) and gabbroic dyke(?) sample SS00-108 (filled squares). (e) Intermediate and felsic samples from the Bocabec Pluton (black circles) and samples from the Utopia Granite (+), all from McLeod (1990). Chondrite-normalizing values are from Sun and McDonough (1989). 
Table 5. Rare-earth element, Hf, and Ta data* from the Moosehorn Plutonic Suite and spatially associated units.

\begin{tabular}{|c|c|c|c|c|c|c|c|c|c|c|c|c|c|c|c|c|}
\hline Sample & $\mathrm{La}$ & $\mathrm{Ce}$ & $\operatorname{Pr}$ & $\mathrm{Nd}$ & $\mathrm{Sm}$ & $\mathrm{Eu}$ & Gd & $\mathrm{Tb}$ & Dy & Ho & Er & $\mathrm{Tm}$ & $\mathrm{Yb}$ & $\mathrm{Lu}$ & $\mathrm{Hf}$ & $\mathrm{Ta}$ \\
\hline \multicolumn{17}{|c|}{ St. Stephen Gabbro - gabbro unit } \\
\hline SS98-29 & 1.164 & 2.800 & 0.476 & 2.707 & 0.933 & 0.619 & 1.302 & 0.215 & 1.424 & 0.279 & 0.797 & 0.110 & 0.705 & 0.098 & 0.428 & 0.187 \\
\hline SS98-32a & 2.636 & 5.672 & 0.766 & 3.609 & 0.986 & 1.081 & 1.284 & 0.222 & 1.537 & 0.323 & 1.012 & 0.158 & 1.107 & 0.162 & 0.359 & 0.271 \\
\hline \multicolumn{17}{|c|}{ Calais Quartz Diorite } \\
\hline SS00-120 & 20.845 & 43.159 & 5.304 & 21.625 & 4.980 & 1.458 & 5.790 & 0.947 & 5.903 & 1.136 & 3.285 & 0.490 & 3.200 & 0.466 & 3.305 & 0.597 \\
\hline SS00-122 & 18.748 & 39.687 & 5.416 & 24.120 & 5.746 & 1.675 & 7.016 & 1.149 & 7.323 & 1.392 & 3.983 & 0.588 & 3.383 & 0.547 & 4.500 & 0.584 \\
\hline SS00-144A & 23.569 & 51.282 & 6.259 & 26.133 & 6.065 & 1.689 & 6.421 & 1.000 & 6.115 & 1.022 & 2.981 & 0.433 & 2.909 & 0.486 & 3.715 & 1.047 \\
\hline SS98-09 & 11.956 & 26.073 & 3.414 & 15.001 & 3.490 & 1.248 & 3.902 & 0.625 & 3.972 & 0.778 & 2.341 & 0.336 & 2.275 & 0.318 & 3.153 & 0.467 \\
\hline SS98-72 & 27.125 & 57.960 & 7.316 & 31.034 & 7.129 & 1.902 & 7.537 & 1.213 & 7.516 & 1.477 & 4.297 & 0.628 & 4.126 & 0.611 & 6.024 & 0.922 \\
\hline \multicolumn{17}{|c|}{ Baring Granite } \\
\hline SS00-104 & 25.574 & 79.216 & 6.992 & 28.172 & 6.713 & 1.106 & 6.829 & 1.212 & 7.772 & 1.544 & 4.567 & 0.687 & 4.582 & 0.651 & 5.916 & 2.184 \\
\hline SS00-108 & 54.481 & 124.342 & 15.847 & 49.000 & 13.389 & 7.952 & 14.539 & 2.151 & 12.605 & 2.238 & 5.997 & 0.784 & 4.860 & 0.703 & 2.344 & 0.437 \\
\hline
\end{tabular}

*Analyses at Memorial University of Newfoundland by ICP-MS, using the $\mathrm{Na}_{2} \mathrm{O}_{2}$ sinter method (Longerich et al. 1990).

\section{Sm-Nd isotopes}

Five samples were analyzed for Sm-Nd isotopes (Table 6). The calculated $\varepsilon_{\mathrm{Nd}}$ at $421 \mathrm{Ma}$ for gabbro sample SS98-9 from the St. Stephen Gabbro is 0.4, with a depleted mantle model age of $1567 \mathrm{Ma}$, whereas two dioritic samples from the Calais Quartz Diorite have higher $\varepsilon_{\mathrm{Nd}}$ values of 1.03 and 3.4 at 421 $\mathrm{Ma}$, with depleted mantle ages of 1184 and $881 \mathrm{Ma}$, respectively. For the Baring Granite, the $\varepsilon_{\mathrm{Nd}}$ is only slightly lower at -0.40 , with a similar depleted mantle age of $1250 \mathrm{Ma}$. The gabbro dyke(?) in the Baring Granite has a positive $\varepsilon_{\mathrm{Nd}}$ of 1.51 . All of these values are well below depleted Mantle values (ca. +7 to 8 at ca. $421 \mathrm{Ma}$ ), showing that significant crustal material was melted to produce even the mafic units in the MPS. On the other hand, the $\varepsilon_{\mathrm{Nd}}$ values, even for the Baring Granite, are too high for the magmas to have had an ancient crustal source (likely to be -7 or less at ca. $421 \mathrm{Ma}$; DePaolo 1988).

These results are consistent with those reported by Whalen et al. (1994), which were in the order of +2 to +3 for the Utopia Granite and granite in the Bocabec Pluton. Gabbro in the Bocabec Pluton yielded a higher value of +5 (all values recalculated to $421 \mathrm{Ma}$ ).

\section{PETROGENSIS}

Field relations and petrological features, as well as geochronology, are consistent with a co-magmatic relationship among the St. Stephen Pluton, Calais Quartz Diorite, Bocabec Pluton, and Baring Granite. The Staples Mountain Gabbro may also be closely related to this suite, but it shows some chemical differences that need to be investigated further.

A likely model is that a mafic magma (possibly mantle- derived) of the MPS was emplaced first and underwent substantial crystal fractionation to produce the mafic and ultramafic St. Stephen Gabbro and the more evolved dioritic magma represented by the Calais Quartz Diorite. The evolved dioritic magmas then mingled with crustal melts of granitic composition, represented by the Baring Granite, to locally produce hybrid rocks such as the granodiorite documented by Fyffe (1971) in the Bocabec Pluton. Disruption of earlier layered mafic bodies by younger granite magmas was proposed by Amos (1963). However, in their study of the Cadillac Mountain intrusive complex, similar to the MPS in age and range of rock types, Wiebe et al. (1997) demonstrated that felsic magmas interacted with subsequent infusions of mafic magma. Such later infusions of mafic magma are represented in the MPS by the Elliott Mountain Diorite and small gabbroic and dioritic bodies scattered through the MPS.

Although the mafic component in the coastal Maine province has generally been considered a mantle melt, the low epsilon $\mathrm{Nd}$ values and especially the small difference in epsilon Nd between the Baring and Utopia granites and the Calais Quartz Diorite suggests a major component of crustal material. Isotopic studies of other plutonic suites in the region may enable a better understanding of magma generation processes.

\section{TECTONIC IMPLICATIONS}

The late Silurian (ca. $421 \mathrm{Ma}$ ) age for components of the MPS is similar to ages reported for other mafic-felsic plutonic complexes of the Coastal Maine magmatic province, although voluminous younger Devonian plutons are also present (e.g., Hogan and Sinha 1989; McLeod 1990; Tucker et al. 2001). Like 
Table 6. Sm-Nd isotopic data for the Moosehorn Plutonic Suite

\begin{tabular}{lcccccccc}
\hline Unit & Sample & $\frac{{ }^{143} \mathrm{Nd}}{144} \mathrm{Nd}$ & $2 \sigma$ & $\frac{{ }^{147} \mathrm{Sm}}{144}$ & $\mu \mathrm{g} / \mathrm{g} \mathrm{Nd}$ & $\mu \mathrm{g} / \mathrm{g} \mathrm{Sm}$ & $\begin{array}{c}\varepsilon_{\mathrm{Nd}} \\
(421 \mathrm{Ma})\end{array}$ & $\mathrm{T}(\mathrm{DM})$ \\
\hline St. Stephen Gabbro & SS98-32a & 0.512581 & 0.000050 & 0.1691 & 3.752 & 1.05 & 0.37 & $1567 \mathrm{Ma}$ \\
Calais Quartz Diorite & SS98-09 & 0.512687 & 0.000050 & 0.1514 & 14.75 & 3.70 & 3.40 & $881 \mathrm{Ma}$ \\
Calais Quartz Diorite & SS00-123 & 0.512571 & 0.000020 & 0.1533 & 18.92 & 4.70 & 1.03 & $1184 \mathrm{Ma}$ \\
Baring Granite & SS00-124 & 0.512484 & 0.000013 & 0.1485 & 34.59 & 8.32 & -0.41 & $1250 \mathrm{Ma}$ \\
Gabbro dyke(?) & SS00-108 & 0.512568 & 0.000017 & 0.1431 & 64.43 & 14.95 & 1.52 & $1086 \mathrm{Ma}$ \\
\hline
\end{tabular}

Notes: Analyses by Alain Potrel, Memorial University of Newfoundland. Sm and Nd contents and Nd isotopic composition were analyzed using a multicollector Finnigan Mat 262 mass spectrometer in static mode. Nd isotopic ratio are normalized to ${ }^{146} \mathrm{Nd} /{ }^{144} \mathrm{Nd}=0.7219$. The reported values were adjusted to La Jolla $\mathrm{Nd}$ standard $\left({ }^{143} \mathrm{Nd} /{ }^{144} \mathrm{Nd}=0.511860\right)$. During the course of data acquisition replicates of the standard gave a mean value of ${ }^{143} \mathrm{Nd} /{ }^{144} \mathrm{Nd}=0.511886 \pm 26(2 \sigma, \mathrm{n}=18)$. The in-run precisions on $\mathrm{Nd}$ isotopic ratio are given at $95 \%$ confidence level. Error on $\mathrm{Nd}$ isotopic compositions are $<0.002 \%$ and errors on the ${ }^{147} \mathrm{Sm} /{ }^{144} \mathrm{Nd}$ ratio are estimated to be less than $0.1 \%$. The $\varepsilon_{\mathrm{Nd}}$ values are calculated using a ${ }^{147} \mathrm{Sm} /{ }^{144} \mathrm{Nd}=0.1967$ and ${ }^{143} \mathrm{Nd} /{ }^{144} \mathrm{Nd}=0.512638$ values for the present day chondrite uniform reservoir (CHUR). ${ }^{147} \mathrm{Sm}$ decay constant is $6.5410^{-12} \mathrm{y}^{-1}$ (Steiger and Jäger, 1977). The depleted mantle model ages, TDM, were calculated both with respect to a D.M. with a $\varepsilon_{\mathrm{Nd} 0}$ value of +10 isolated from the CHUR since $4.55 \mathrm{Ga}$ and following a linear evolution with respect to the De Paolo (1988) mantle model.

the MPS, many of the other Silurian plutons are bimodal, and display mingling relationships that suggest that the mafic and felsic components were contemporaneous (e.g., Hogan and Sinha 1989; Wiebe et al. 1997). Although these plutons are generally considered to be related to the "Acadian orogeny", the details of tectonic activity during this protracted orogenic event are unclear. Widespread evidence for voluminous late Silurian volcanic and plutonic activity throughout the coastal Maine magmatic province and adjacent New Brunswick shows that igneous activity was a major characteristic of this event, but the specific tectonic setting is uncertain.

The bimodal character of the plutons, and their tendency to A-type affinities, has led to the suggestion that the magmatism was related to regional extension and mafic underplating (e.g., Hogan and Sinha 1989). However, regional tectonic models (e.g., Robinson et al. 1998; van Staal et al. 1998; Tucker et al. 2001) are more consistent with plate convergence and subduction in the Late Silurian. Although somewhat ambiguous, chemical data from the MPS are more indicative of calc-alkalic affinity and a subduction environment than within-plate extension (Fig. 10). One interpretation that may be consistent with both ideas is that Late Silurian plutons in the coastal Maine magmatic province formed in a back-arc position with respect to the early Silurian Kingston arc (Fyffe et al. 1999; Barr et al. 2002). Isotopic data do not indicate a major component of directly mantle-derived magmas in these suites, although isotopic data are not yet available from the more mafic components. Melts may have been generated by large-scale melting of relatively primitive arc-type crust underlying the Mascarene and Ellsworth terranes. The presence of such crust has been suggested by isotopic data from southern New Brunswick (Whalen et al. 1994; Samson et al. 2000).

\section{CONCLUSIONS}

This work has demonstrated that the St. Stephen Gabbro, Calais Quartz Diorite, and Baring Granite components of the Moosehorn Plutonic Suite are approximately contemporaneous and late Silurian in age. The close petrochemical similarity of the St. Stephen Gabbro and Calais Quartz Diorite to the mafic and intermediate components of the Bocabec Pluton of the Saint George Batholith suggests that all of these plutons were comagmatic. The granitic component of the Bocabec Pluton is generally more similar to the Baring Granite than to the Utopia Granite, which is more evolved. The Elliott Mountain Diorite shows petrological differences that suggest that it may be somewhat younger than the other units of the MPS, although the number of samples is limited and more work is required to better define the characteristics of the Elliott Mountain Diorite and its relationship to the Bocabec Pluton and Calais Quartz Diorite. The Staples Mountain Gabbro is unlike the other mafic plutons of the MPS in its iron-enrichment trend, and is therefore likely to be a separate intrusion, although of similar age. Neodymium isotopic data show that even the mafic parts of these plutons have a significant crustal component in their source, but the values even in granitic samples are too high for significant amounts of ancient crustal material to be involved. Their petrochemical features are most consistent with origin in a supra-subduction zone extensional environment (back-arc basin) in relatively young continental crust.

\section{ACKNOWLEDGEMENTS}

We thank L.R. Fyffe (NB Department of Natural Resources) for permission to do additional work on his thesis samples, 
and Dr. D. Lentz, UNB, for providing the thin sections and sample powders from the thesis collection. Kay Thorne and Dave Lentz kindly allowed us to include their unpublished chemical data in our Table 4 (samples Fyffe 13, 38, 42, 43). Owen Gaskill permitted us to use some photographs from his B.Sc. honours thesis in Fig. 3. Field work by M. Hill was supported by the Maine Geological Survey. Comments by journal reviewers Spike Berry and Malcolm McLeod were helpful in improving the manuscript and especially in motivating the authors to change the name to Moosehorn Plutonic Suite.

\section{REFERENCES}

Аввотт, R.N. 1977. Petrology of the Red Beach granite near Calais, Maine. Unpublished $\mathrm{PhD}$ thesis, Harvard University, Cambridge, Massachusetts, 223 p.

Аввотт, R.N. 1986. Bedrock geology of the Red Beach, Robbinson, and Devil's Head 7.5' quadrangles, Maine. Maine Geological Survey, Open - File Report 86-73, 36 p.

Amos, D.H. 1963. Petrography and age of plutonic rocks, extreme southeastern Maine. Geological Society of America, Bulletin, 74, pp. 169-194.

Barr, S.M., White, C.E., \& Miller, B.V. 2002. The Kingston terrane, southern New Brunswick, Canada: Evidence for a Silurian volcanic arc. Geological Society of America Bulletin 114, pp. 964-982.

Coughlin, S. 1986. Geology of the Staples Mountain Complex, Calais quadrangle, eastern Maine. M.Sc. thesis, Queens College, Flushing, New York, 138 p.

DePaolo, D.J. 1988. Neodymium isotope geochemistry. New York, Springer-Verlag, $187 \mathrm{p}$.

El Bouseily, A.M., \& El SokKary, A.A. 1975. The relation between $\mathrm{Rb}, \mathrm{Ba}$, and $\mathrm{Sr}$ in granitic rocks. Chemical Geology, 16, pp. 207-219.

FyFFe, L.R. 1971. Petrogenesis of the adamellite - diorite transition, southwestern New Brunswick. MSc thesis, University of New Brunswick, Fredericton, New Brunswick, 131 p.

FyfFe, L.R. 1990. Geology of the Potters Lake area (NTS 21G/ 03f), Charlotte County, New Brunswick. New Brunswick Department of Natural Resources and Energy, Minerals and Energy Division, Plate 90-150.

FyfFe, L.R., \& Fricker, A. 1987. Tectonostratigraphic terrane analysis of New Brunswick. Atlantic Geology, 23, pp. 113-122.

Fyffe, L.R., Pickerill, R.K., \& Stringer, P. 1999. Stratigraphy, sedimentology and structure of the Oak Bay and Waweig formations, Mascarene Basin: implications for the paleotectonic evolution of southwestern New Brunswick. Atlantic Geology, 35, pp. 59-84.

Gaskill, O.D. 1999. Petrology of the St. Stephen Pluton and associated sulphide deposits, southern New Brunswick. B.Sc. Honours thesis, Acadia University, Wolfville, Nova Scotia, 88 p.
HiLl, M. 1991. Rocks of the Calais area, southeastern Maine. In New England Intercollegiate Geological Conference Guidebook. Edited by A. Ludman. pp. 266-285.

Hill, M., \& Аввотт, R.N. 1989.Commingled gabbroic and granitic magmas in the northern Bays-of-Maine Igneous Complex, Calais area, Maine. In Studies in Maine Geology - Igneous and metamorphic geology. Edited by R.D. Tucker and R.G. Marvinney. 4, pp. 35-43.

Hogan, J.P., \& SinHA, A.K. 1989. Compositional variation of plutonism in the Coastal Maine Magmatic Province: mode of origin and tectonic setting. In Studies in Maine Geology - Igneous and metamorphic geology. Edited by R.D. Tucker and R.G. Marvinney. 4, pp. 1-33.

Houston, R.S. 1956. Genetic study of some pyrrhotite deposits of Maine and New Brunswick: Maine Geological Survey, Bulletin, 7, $112 \mathrm{p}$.

Hussey, A.M., II, Chapman, C.A., Doyle, R.G., Osberg, P.H., Pavlides, L., \& Warner, J., (compilers). 1967. Preliminary geologic map of Maine: Maine Geological Survey, scale 1:500 000 .

Hutchinson, C.S. 1974. Laboratory Handbook of Petrographic Techniques. Wiley Interscience, New York, $527 \mathrm{p}$.

Irvine, T.N., \& BARAGAR, W.R.A. 1971. A guide to chemical classification of the common volcanic rocks. Canadian Journal of Earth Sciences, 8, pp. 523-548.

JURINSKI, J.B. 1987. The Baring pluton: contaminated granite of the Moosehorn Plutonic Suite. B.Sc. thesis, Virginia Polytechnic Institute and State University, Blacksburg, Virginia, $48 \mathrm{p}$.

JurinsKi, J.B. 1990. Petrogenesis of the Moosehorn Plutonic Suite, Maine. M.Sc. thesis, Virginia Polytechnic Institute and State University, Blacksburg, Virginia, 125 p.

Koorman, G.J. 1996. St. Stephen nickel deposits, Charlotte County, New Brunswick - A compilation. New Brunswick Department of Natural Resources and Energy, Minerals and Energy division, Open File 96-19, 39 p.

Longerich, H., JenNer, G.A., Fryer, B.J., \& JACKson, S.E. 1990. Inductively coupled plasma- mass spectrometric analysis of geochemical samples. A critical evaluation based on case studies: Chemical Geology, 83, pp. 105-118.

Ludman, A., \& Hill, M. 1986. Bedrock geology of the Calais 15' Quadrangle, eastern Maine. Maine Geological Survey, Open File 86-72.

Ludman, A., \& Hill, M. 1990. Bedrock geology of the Calais 15' Quadrangle, eastern Maine. Maine Geological Survey, Open File 90-27, 32 p.

McDougall, I. ANd Harrison, T.M. 1999. Geochronology and Thermochronology by the ${ }^{40} \mathrm{Ar} /{ }^{39} \mathrm{Ar}$ Method (Second Edition). Oxford University Press, New York, 269.

McLaughlin, K.J. 2003. The Moosehorn Plutonic Suite of southwestern New Brunswick and southeastern Maine: Petrology, geochemistry, and tectonic setting. Unpublished MSc thesis, Acadia University, Wolfville, Nova Scotia, $307 \mathrm{p}$. 
McLeod, M.J. 1990. Geology, Geochemistry, and Related Mineral Deposits of the Saint George Batholith; Charlotte, Queens, and Kings Counties, New Brunswick. New Brunswick Department of Natural Resources and Energy, Mineral Resources, Mineral Resource Report 5.

McLeod, M.J., Johnson, S.C., \& Ruitenberg, A.A. 1994. Geological map of southwestern New Brunswick. New Brunswick Department of Natural Resources and Energy, Mineral Resources Map NR-5.

Miyashiro, A., \& Shido, F. 1975. Tholeiitic and calc-alkaline series in relation to the behaviours of titanium, vanadium, chromium, and nickel. American Journal of Science, 274, pp. 265-277.

Paktunc, A.D. 1989. Petrology of the St. Stephen intrusion and the genesis of related nickel-copper sulfide deposits, Economic Geology, 84, pp. 817-840.

Pearce, J.A. and Cann, J.R. 1973. Tectonic setting of basic volcanic rocks determined using trace element analysis. Earth and Planetary Science Letters, 19, pp. 290-300.

Pearce, J.A., \& Norry, M.J. 1979. Petrogenetic implications of $\mathrm{Ti}, \mathrm{Zr}, \mathrm{Y}$, and $\mathrm{Nb}$ variations in volcanic rocks. Contributions to Mineralogy and Petrology, 69, pp. 33-47.

Pearce, J.A., Harris, N.B.W., \& Tindle, A.G. 1984. Trace element discrimination diagrams for the tectonic interpretation of granitic rocks. Journal of Petrology, 25, pp. 956-983.

Robinson, P., Tucker, R.D., Bradley, Berry, H.N., \& Osberg, P.H. 1998. Paleozoic orogens in New England, USA. GFF, 120, pp. 119-148.

Ruitenberg, A.A., \& McCutcheon, S.R. 1978. Field guide to lower Paleozoic sedimentary and volcanic rocks of southwestern New Brunswick. In Ludman, A., editor, New England Intercollegiate Geological Conference Guidebook, $70^{\text {th }}$ Annual Meeting, pp.133-144.

Samson, S.D., \& Alexander JR., E.C. 1987. Calibration of the inter-laboratory ${ }^{40} \mathrm{Ar} /{ }^{39} \mathrm{Ar}$ dating standard, MMhb-1. Chemical Geology, 66, pp. 27-34.

SAMson, S.D., BarR, S.M., White, C.E. 2000. Nd isotopic characteristics of terranes within the Avalon Zone, southern New Brunswick. Canadian Journal of Earth Sciences, 37, pp. 1039-1052.

Schmitz, M.D. \& Bowring, S.A. 2003. Constraints on the thermal evolution of continental lithosphere from $\mathrm{U}-\mathrm{Pb}$ accessory mineral thermochronometry of lower crustal xenoliths, southern Africa. Contributions to Mineralogy and Petrology, 144, pp. 592-618.

Seaman, S.J., Wobus, R.A., Wiebe, R.A., Lubick, N.., \& BowRING, S.A. 1995. Volcanic expression of bimodal magmatism: The Cranberry Island - Cadillac Mountain Complex, coastal Maine. Journal of Geology, 100, pp. 395-409.

SeAman, S.J., Scherer, E.E., Wobus, R.A., Zimmer, J.H., \& SALES, J.G. 1999. Late Silurian volcanism in coastal Maine: The Cranberry Island series: Geological Society of America Bulletin, 111, pp. 686-708.
SHERVAIs, J.W. 1982. Ti-V plots and the petrogenesis of modern and ophiolitic magmas. Earth and Planetary Sciences Letters, 59, pp. 101-118.

StaCEY, J.S., \& KRAMERS, J.D. 1975. Approximation of terrestrial lead isotope evolution by a two-stage model. Earth and Planetary Science Letters 26, pp. 207-221.

STEIGER, R.H., \& JÄGER, H. 1977. Subcommission on geochronology: convention on the use of decay constants in geo- and cosmochronology. Earth and Planetary Science Letters, 36, pp. 359-362.

Stewart, D.B., Tucker, R.D., Ayuso, R.A., \& Lux, D.R. 2001. Minimum age of the Neoproterozoic Seven Hundred Acre Island Formation and the tectonic setting of the Islesboro Formation, Islesboro Block, Maine. Atlantic Geology, 37, pp. 41-59.

Sun, S.S., \& McDonough, W.F. 1989, Chemical and isotopic systematics of oceanic basalts: implications for mantle composition and processes. In Magmatism in the ocean basins. Edited by A.D. Saunders and M.J. Norry. Geological Society Special Publication, 42, pp. 313-345.

Thorne, K.G., \& Lentz, D.R. 2001. Geochemistry and petrogenesis of the East Branch Brook metagabbroic dykes in the Sawyer Brook fault zone, Clarence Stream gold prospect, southwestern New Brunswick. Atlantic Geology, 37, pp. 175-190.

Tucker, R.D., Osberg, P.H., \& Berry, H.N. 2001. The geology of a part of Acadia and the nature of the Acadian orogeny across central and eastern Maine. American Journal of Science, 301, pp. 205-260.

van Staal, C.R., Dewey, J.F., Niocaill, C.M., \& McKerRow, W.S. 1998. The Cambrian-Silurian tectonic evolution of the northern Appalachians and British Caledonides: history of a complex, west and southwest Pacific-type segment of Iapetus. In Lyell: the Past is the Key to the Present. Edited by D.J. Blundell and A.C. Scott. Geological Society, London, Special Publications, 143, pp. 199-242.

Wanless, R.K., Stevens, R.D., LaChance, G.R., \& Delabio, R.D. 1973. Age determinations and geological studies (K-Ar isotopic ages report 11). Geological Survey of Canada Paper 73-2, pp. 84-87.

West, D.P., Ludman, A., Lux, D.R. 1992. Silurian age for the Pocomoonshine gabbro-diorite, southeastern Maine and its regional tectonic implications. American Journal of Science, 292, pp. 253-273.

Westerman, D.S. 1972. Petrology of the Pocomoonshine Gabbro-Diorite, Big Lake, Quadrangle, Maine. Ph.D. dissertation, Lehigh University, $175 \mathrm{p}$.

Whalen, J.B., Currie, K., \& Chappell, B.W. 1987. A-type granites: geochemical characteristics, discrimination and petrogenesis. Contributions to Mineralogy and Petrology, 95, pp. 407-419.

Whalen, J.B., Jenner, G.A., Currie, K.L., Barr, S.M., LongStAFFe, F.J., Hegner, E. 1994. Geochemical and isotopic characteristics of granitoids of the Avalon Zone, southern 
New Brunswick: possible evidence for repeated delamination events. The Journal of Geology, 102, pp. 269-282.

Wiebe, R.A., Holden, J.B., Coombs, M.L., Wobus, R.A., Schuh, K.J., \& Plummer, B.P. 1997. The Cadillac Mountain intrusive complex, Maine: The role of shallow-level magma chamber processes in the generation of A-type Granites. In The Nature of Magmatism in the Appalachian Orogen. Edited by A.K.Sinha, J.B. Whalen, and J.P. Hogan. Geological Society of America. Memoir 191, pp. 397-418.
Winchester, J.A., \& Floyd, P.A. 1977. Geochemical discrimination of different magma series and their differentiation products using immobile elements. Chemical Geology, 20, pp. 325-343.

Editorial responsibility:David Gibson 